\title{
Urbanisation and nest building in birds: a review of threats and opportunities
}

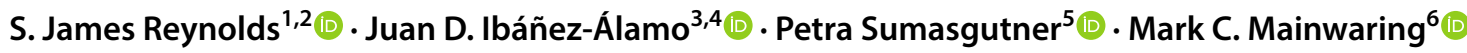

Received: 21 December 2018 / Revised: 11 March 2019 / Accepted: 13 March 2019 / Published online: 11 April 2019

(c) The Author(s) 2019

\begin{abstract}
The world is urbanising rapidly, and it is predicted that by $2050,66 \%$ of the global human population will be living in urban areas. Urbanisation is characterised by land-use changes such as increased residential housing, business development and transport infrastructure, resulting in habitat loss and fragmentation. Over the past two decades, interest has grown in how urbanisation influences fundamental aspects of avian biology such as life-history strategies, survival, breeding performance, behaviour and individual health. Here, we review current knowledge on how urbanisation influences the nesting biology of birds, which determines important fitness-associated processes such as nest predation and community assembly. We identify three major research areas: (i) nest sites of birds in urban areas, (ii) the composition of their nests, and (iii) how these aspects of their nesting biology influence their persistence (and therefore conservation efforts) in urban areas. We show that birds inhabiting urban areas nest in a wide variety of locations, some beneficial through exploitation of otherwise relatively empty avian ecological niches, but others detrimental when birds breed in ecological traps. We describe urban-associated changes in nesting materials such as plastic and cigarette butts, and discuss several functional hypotheses that propose the adaptive value and potential costs of this new nesting strategy. Urban areas provide a relatively new habitat in which to conserve birds, and we show that nestboxes and other artificial nest sites can be used successfully to conserve some, but not all, bird species. Finally, we identify those subject areas that warrant further research attention in the hope of advancing our understanding of the nesting biology of birds in urban areas.
\end{abstract}

Keywords Birds $\cdot$ Community $\cdot$ Conservation $\cdot$ Ecological trap $\cdot$ Nest design and site selection $\cdot$ Pollution

\section{Introduction}

Communicated by F. Bairlein.

This article is a contribution to the Topical Collection 27th International Ornithological Congress, Vancouver, Canada, 19 to 26 August 2018

S. James Reynolds

J.Reynolds.2@bham.ac.uk

1 Centre for Ornithology, School of Biosciences, College of Life \& Environmental Sciences, University of Birmingham, Edgbaston, Birmingham B15 2TT, UK

2 The Army Ornithological Society (AOS), c/o Prince Consort Library, Knollys Road, Aldershot, Hampshire GU11 1PS, UK

3 Groningen Institute for Evolutionary Life Sciences, University of Groningen, 9700 Groningen, The Netherlands
We live in a world dominated by heavily human-impacted ecosystems such as warming oceans polluted by plastic and petrochemicals, and from which marine life has been over-harvested, forests either completely lost or heavily fragmented, rural areas farmed ever more intensively, and rapidly expanding urban areas (Ripple et al. 2017). Of all of

4 Present Address: Department of Zoology, Faculty of Sciences, University of Granada, E-18071 Granada, Spain

5 Department of Biological Sciences, FitzPatrick Institute of African Ornithology, DST-NRF Centre of Excellence, University of Cape Town, Rondebosch, Cape Town, South Africa

6 Division of Biological Sciences, University of Montana, Missoula, MT 59812, USA 
these human-transformed environments, arguably it is urban areas that have been transformed most extensively (Johnson and Munshi-South 2017). By 2008, more than half of the world's human population was living in urban areas (United Nations 2014), with urbanisation continuing globally and rapidly (Seto et al. 2012). Accompanying this burgeoning human population in our towns and cities has been the emergence of the concept of the 'urban bird' (e.g., Evans et al. 2011; Marzluff 2014). Although such urban birds may be adapted to urban environments, the urbanisation process profoundly affects the majority of birds because it often involves the irreversible replacement of areas of natural and semi-natural rural habitats such as farmland and woodland with concreted areas of buildings and roads interspersed with gardens, parks and other green spaces (Forman 2014; Shanahan et al. 2014).

While urban birds face many challenges (reviewed in Marzluff 2017) that include exposure to novel predators (López-Flores et al. 2009), food sources (Jones and Reynolds 2008; Reynolds et al. 2017; Jones 2018), habitat types (Rodewald et al. 2013), thermal ranges (Davis et al. 2014a), and stressors such as noise (e.g., Fuller et al. 2007; Sierro et al. 2017), light (e.g., Kempenaers et al. 2010; Dominoni et al. 2013; Holveck et al. 2019) and air pollution (e.g., Isaksson 2015), their expansion and persistence in urban centres offers us many opportunities to understand processes of adaptation to urban living and the development of urban spaces as conservation areas for wildlife more generally. The responses of birds to extrinsic factors in the urban environment play out through processes such as synurbisation (reviewed in Luniak 2004), biotic homogenisation (McKinney 2006; Galbraith et al. 2015; Ibáñez-Álamo et al. 2017a), and ecological traps (Dias 1996; Leston and Rodewald 2006, Sumasgutner et al. 2014a).

It is now rare to attend scientific mainstream ornithological meetings where there is not at least one session devoted to urban birds, and indeed, there are organisations such as the Urban Wildlife Working Group (http://urbanwildlifegr oup.org/) that host entire annual conferences devoted to public awareness and management of urban wildlife, including birds. Increasing ornithological interest in urban birds, and especially in their behaviour and ecology, has resulted in the publication of numerous books in this subject area (e.g., Bird et al. 1996; Marzluff et al. 2001; Lepczyk and Warren 2012; Gil and Brumm 2013; Marzluff 2014; Murgui and Hedblom 2017; Jones 2018). Despite this, Reynolds and Deeming (2015) argued that compared with our knowledge of avian life history, behavioural ecology, distribution and abundance, our understanding of the nesting biology of birds is rather limited. This is particularly striking within the urban context. Birkhead (2015) singled out the nesting biology of birds as being fertile ground for future research, even in meeting the primary fundamental scientific aim of obtaining first nest descriptions of most (i.e., an estimated $55 \%$; W. Jetz, pers comm) of the world's avifauna (Reynolds and Deeming 2015). It is shocking that we lack such basic information about extant bird species; such nest descriptions will inevitably promote a greater understanding of broader disciplines such as ecology and evolution of birds.

Given that birds invest considerable time and energy in nest building and maintenance (Hansell 2000; Stanley 2002), it is surprising that the nesting biology of birds has been rather neglected as a research focus compared to other aspects of their breeding biology (Deeming and Reynolds 2015a). We now need to go beyond studies that describe how the breeding performance of birds varies with urbanisation (e.g., Tremblay et al. 2003; Partecke et al. 2004; Hedblom and Söderström 2012). As part of this, a focus on investments of time and energy in the location of suitable nest sites and the subsequent construction and maintenance of nest structures would greatly enhance our understanding of the life history and ecology of urban birds (Deeming and Reynolds 2015b). Discussions are currently under way between the authors of this paper and the wider ornithological community about how we can carry out concerted, complementary and meaningful research that is performed in a standardised manner on urban birds at a global scale within urban study sites. Therefore, we have taken this opportunity to write about just one subject area (of many) that we feel has the potential to bring field ornithologists together, whether they are professional or citizen scientists (Greenwood 2007; Dickinson and Bonney 2012; Cooper 2017).

We have chosen to direct the focus of this paper to three different subject areas related to the nesting biology of birds in urban areas. First, we address where urban birds nest, which is essential in making assessments about nest site availability in cities (Kark et al. 2007), allowing subsequent estimation of important measures such as breeding density of study species (Šálek et al. 2015), and heterospecific and conspecific competition (Evans et al. 2009a, 2009b). Secondly, we explore the form of urban nest design allowing quantification of investment in nest construction and maintenance by breeding birds (Mainwaring et al. 2014a) as well as potential relationships between the structure and composition of nests and their fitness-associated consequences for urban birds (e.g., Reid et al. 2002). Thirdly, we discuss to what extent the nesting biology of target species can inform conservation actions and ultimately policy (Collar and Butchart 2014; Deeming and Jarrett 2015). Conserving birds in urban areas may seem to be a low priority for conservationists, given that they inhabit a highly artificial and generally biodiversity-poor environment. However, numerous studies have shown that birds inhabiting urban areas comprise almost all of the interactions that most people living in urban areas have, and that such interactions provide psychological benefits to those people (reviewed in Cox 
et al. 2017). Such interactions also allow human-wildlife engagement to mediate opportunities for raising conservation awareness. Furthermore, some threatened species have important populations in urban areas (e.g., UK gulls [Laridae]—Raven and Coulson 1997; German Common Swifts [Apus apus] —Schaub et al. 2015), and so we consider that many urban birds are of conservation concern. Finally, we identify key areas for future research that we hope will place the nesting biology of birds at the core of our understanding of how avian species adapt to urban life across the globe (Kark et al. 2007; Croci et al. 2008; Sol et al. 2014).

\section{Urban nest sites}

In this section, we consider how the availability of nest sites in native and non-native vegetation, houses, uninhabited buildings, a variety of anthropogenic structures such as metal pipes and bridges, and provision of nestboxes influence birds nesting in urban areas worldwide (summarised in Table 1; Fig. 1). Native trees and flowering plants have been progressively removed from urban areas because they are considered 'weeds'; they are replaced with non-native vegetation (Marzluff et al. 2001; Reale and Blair 2005; Forman 2014). Illustratively, an average of 2.4 native plant species were lost annually over a period of seven decades in cities in Indiana in the USA, whilst over the same period 1.4 species of non-native plant species were introduced per annum (Dolan et al. 2011). Loss of native vegetation can present problems to breeding passerines whose reproductive success is often higher in native, as opposed to non-native, vegetation (Borgmann and Rodewald 2004; Rodewald et al. 2010; but see Meyer et al. 2015). Despite birds often having higher levels of breeding success in native vegetation, Vincze et al. (2017) used a

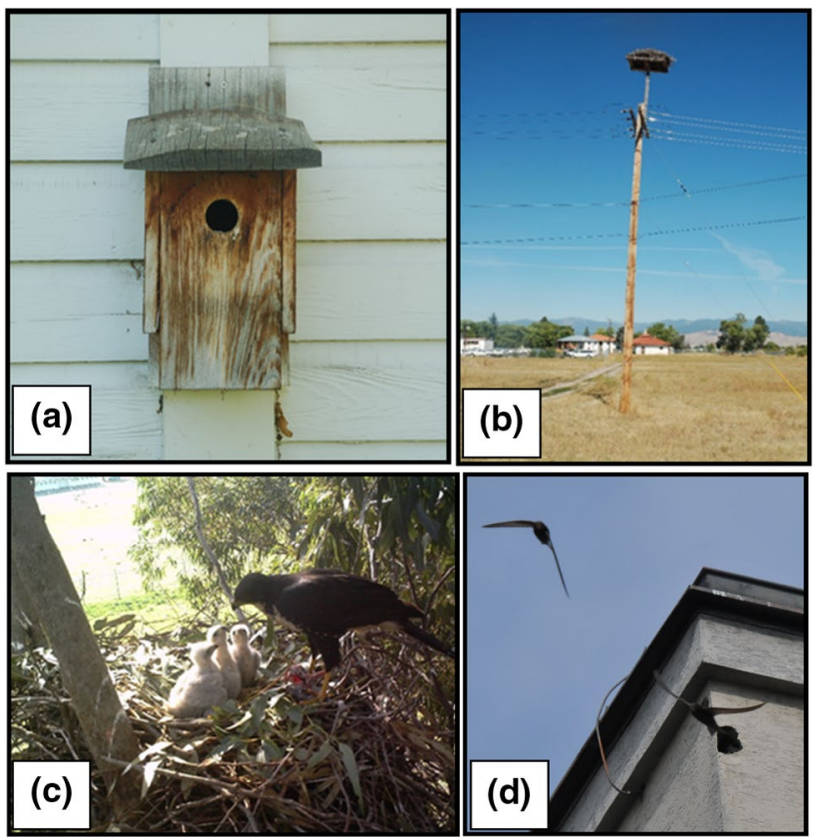

Fig. 1 Nest sites of birds in urban areas include: a a nestbox for passerines; $\mathbf{b}$ an artificial nest platform for raptors such as Ospreys (Pandion haliaetus) (Photo: Mark Mainwaring); $\mathbf{c}$ an open nest in non-native vegetation such as that of Black Sparrowhawks (Accipiter melanoleucus) (Photo: Petra Sumasgutner); and $\mathbf{d}$ a nesting hole of a Common Swift (Apus apus) (Photo: Ferdinand Schmeller/MA22)

meta-analysis to show that the detection of birds' nests by predators generally declined with increasing urbanisation. How this is related to the replacement of native with nonnative vegetation remains unclear.

Many studies of passerines report that nest sites in nonnative vegetation act as ecological traps (e.g., Borgmann and Rodewald 2004; Rodewald et al. 2010). This is thought to be because breeding passerines forage close to their nest

Table 1 A list of the main categories of nest substrates used by urban birds and the main advantages and disadvantages to birds nesting in them

\begin{tabular}{|c|c|c|}
\hline Nest substrate & Advantages & Disadvantages \\
\hline Native vegetation & $\begin{array}{l}\text { Likely to be optimal breeding sites, as birds are well } \\
\text { adapted over evolutionary time }\end{array}$ & $\begin{array}{l}\text { Majority of such sites have been lost through increasing } \\
\text { intensity of urbanisation }\end{array}$ \\
\hline Non-native vegetation & $\begin{array}{l}\text { Most commonly available breeding habitat type and sup- } \\
\text { ports insect prey base for prolonged periods compared } \\
\text { with native vegetation }\end{array}$ & $\begin{array}{l}\text { Generally supports a reduced insect prey biomass compared } \\
\text { with native vegetation. May therefore act as an ecological } \\
\text { trap }\end{array}$ \\
\hline Houses & $\begin{array}{l}\text { Widely available nest site for cavity nesters at sites where } \\
\text { nesting opportunities are otherwise limited }\end{array}$ & $\begin{array}{l}\text { Householders may be opposed to birds using their homes as } \\
\text { breeding sites }\end{array}$ \\
\hline Uninhabited buildings & $\begin{array}{l}\text { Safe (undisturbed) nest sites often in areas where prey are } \\
\text { abundant }\end{array}$ & $\begin{array}{l}\text { May be ecological traps as evidenced by breeding birds } \\
\text { paying fitness costs }\end{array}$ \\
\hline $\begin{array}{l}\text { Anthropogenic } \\
\text { (non-residential) } \\
\text { structures }\end{array}$ & $\begin{array}{l}\text { Provision of nest sites where otherwise they are in limited } \\
\text { supply }\end{array}$ & $\begin{array}{l}\text { May be ecological traps due to their only temporary avail- } \\
\text { ability }\end{array}$ \\
\hline Nestboxes & $\begin{array}{l}\text { Nest sites in public parks, and public and private gardens } \\
\text { suffering lower rates of predation compared with natural } \\
\text { sites }\end{array}$ & $\begin{array}{l}\text { May be ecological traps due to birds breeding at high } \\
\text { density but under conditions of intense competition for } \\
\text { sometimes limited food }\end{array}$ \\
\hline
\end{tabular}


sites, where non-native plants support a lower food base for nestlings than do native plants (Ortega et al. 2006). These urban-associated changes in vegetation could also partially explain why urban areas fledge fewer offspring per breeding attempt than rural areas, although annual productivity is generally higher due to earlier and/or longer breeding seasons which allow more breeding attempts per season (Chamberlain et al. 2009). Other studies, however, have reported that birds nesting in non-native vegetation have at least equal levels of breeding success to conspecifics in native vegetation (e.g., Schlossberg and King 2010; Meyer et al. 2015). Such equivocal findings reflect the conclusions of the most recent review in this subject area by Stinson and Pejchar (2018). They reviewed 32 studies examining 133 songbird species' responses to nesting in non-native vegetation. Although $35 \%$ of studies found some evidence for non-native plants acting as ecological traps through negative impacts on the birds' productivity, fledgling and adult survival, nestling condition and brood parasitism rates, $31 \%$ of studies found positive impacts on the same parameters.

Inhabited buildings such as houses or blocks of flats commonly provide nest sites for species such as Common Swifts (Fig. 1d), Common Starlings (Sturnus vulgaris) and House Sparrows (Passer domesticus) that nest in the eaves of houses (Mainwaring 2015), although their nest sites have been the subject of little research. This is somewhat surprising given that such species are urban specialists that overwhelmingly breed at unnatural nest sites, which means, in turn, that they are likely to have wider geographic ranges and larger population sizes as a result of the expansion of urban areas (De Laet and Summers-Smith 2007). Inhabited buildings also provide nest sites for waders such as Eurasian Oystercatchers (Haematopus ostralegus) (Munro 1984) and gulls that nest on rooftops (Vermeer et al. 1988; Raven and Coulson 1997; Soldatini et al. 2008). The widespread availability of nest sites on rooftops has facilitated dramatic population increases in urban gulls over the past few decades (Soldatini et al. 2008). Much has been made of this by many local authorities and the media, because the growing number of urban gulls increases the likelihood of conflict between birds and humans, with associated public health impacts. For example, there is a significant chance of faecal contamination of urban water supplies (Hatch 1996) and of pathogens such as bacteria and viruses being spread. Studies have suggested that European Herring Gulls (Larus argentatus) act as vectors in outbreaks of Salmonella montevideo in sheep (Ovis aries) and cattle (Bos taurus) in Scotland (Coulson et al. 1983) and that Olrog's Gulls (Larus atlanticus) and Kelp Gulls (Larus dominicanus) act as vectors for a range of zoonotic pathogens in Argentina (La Sala et al. 2013). Nesting close to houses may also induce behavioural changes in birds. For example, Møller and Díaz (2018) found that birds nesting closer to inhabited buildings reduced their anti-predator behaviours because they were exposed to fewer predators than conspecifics nesting further away from houses.

A range of bird species nest in large numbers either on or in uninhabited buildings in urban areas that include factories, shops and abandoned residential buildings. For example, more than 500 pairs of Glaucous-winged Gulls (Larus glaucescens) nested on roofs along the waterfront in Vancouver, BC, Canada (Vermeer et al. 1988), and 11,047 pairs of European Herring Gulls and 2544 pairs of Lesser Black-backed Gulls (Larus fuscus) nested on buildings and other man-made structures in the UK (Raven and Coulson 1997). Uninhabited buildings in cities appear to provide breeding opportunities that are as good for urban gulls as rural habitats, with populations exhibiting equivalent breeding performance (Soldatini et al. 2008). Even though birds such as gulls and other urban species widely use uninhabited buildings as nest sites, they also nest in rural areas and are therefore not completely reliant upon uninhabited buildings to provide nesting opportunities. In contrast, urban specialists such as Common Swifts and House Sparrows nest almost exclusively on uninhabited buildings in urban areas (De Laet and Summers-Smith 2007), which means that their populations are likely to be closely tied to the availability of these structures. Therefore, we need to know much more about the reliance of such urban specialists upon uninhabited buildings. In summary, nest sites on uninhabited buildings may be widely available, but additional work is needed to determine how advantageous they are for breeding birds compared with other urban sites.

Birds also nest either on or in a variety of anthropogenic structures such as bridges and metal pipes (Mainwaring 2015). Bridges over both water and roads provide safe breeding sites for birds in locations where nest sites may well be limited, although traffic does pose a risk for birds nesting over roads, because they collide with cars (Brown and Brown 2013). Whilst the majority of studies simply state that birds use such structures as nest sites, few have quantified their importance relative to other nest substrates. A notable exception was a study by Lesiński (2000) that examined nest sites of a range of hole-nesting passerine species in a suburb of Warsaw, Poland. It was found that many birds were nesting inside vertical pipes of fences, where approximately $80 \%$ of the local Great Tit (Parus major) population were estimated to be breeding. While for some avian taxa, therefore, pipes and other anthropogenic structures provide unlikely breeding opportunities in locations where nest sites may be in short supply, others such as pigeons and doves (Columbiformes) are sometimes deterred from exploiting such opportunities through the placement of obstructing metal pins that prevent them from alighting on window ledges, under bridges and on other similar structures. These structures often only offer ephemeral nesting opportunities 
to birds because either they are temporary supporting structures or they are the first piece of infrastructure that falls into disrepair, sometimes leading to their removal because of public safety concerns. Therefore, anthropogenic structures may also act as ecological traps by attracting birds to breed in locations that ultimately reduce their fitness (Schlaepfer et al. 2002).

Nestboxes, artificial platforms and even artificial burrows are widely provided for birds such as passerines (Passeriformes) (e.g., Remacha and Delgado 2009; Schaub et al. 2015; Reynolds et al. 2016; Duckworth et al. 2017; Lambrechts et al. 2017; Fig. 1a), storks (Ciconiiformes) (e.g., Tryjanowski et al. 2009), raptors (Falconiformes) (e.g., Postupalsky and Stackpole 1974; Tigner et al. 1996; Fig. 1b), owls (Strigiformes) (e.g., Smith et al. 2005) and swifts (Apodiformes) (e.g., Schaub et al. 2015) within urban landscapes. Whilst at first sight nestboxes provided by individual householders may appear to provide few nesting opportunities for urban birds, nestboxes can be highly abundant in some urban areas. For example, it was estimated that there were 45,500 nestboxes in the city of Sheffield in northern England (Gaston et al. 2005), and Davies et al. (2009) estimated that there were at least 4.7 million nestboxes in gardens in Great Britain. These studies indicate that nestboxes can provide abundant nest sites in some urban areas in some countries (e.g., the UK, the USA), where they certainly address shortfalls in nest site availability. However, nestboxes might be advantageous for birds only when located in areas of high food abundance, and otherwise can act as an ecological trap (Demeyrier et al. 2016). We also acknowledge that nestboxes are not provided to birds globally.

Within urban areas, birds use a wide variety of nest sites that offer benefits but also detriments to birds occupying them, as summarised in Table 1. There is, however, a general trend for the variety of potential nest sites to decline as the urbanisation process advances, but with some nest sites that are either in or on houses, for example, increasing in availability to breeding birds (Rao and Koli 2017). Although it is unlikely that a reduction in the availability of nest sites has been responsible for changes in bird assemblages inhabiting urban areas (Oliveira Hagen et al. 2017), homogeneity of nest site form is reflected in an overall decline in species richness in urban areas; some species, of course, may exploit more breeding opportunities as a result (Ibáñez-Álamo et al. 2017a). The limitations of avian breeding potential in cities caused by the scarcity of nest sites can however be addressed by the provision of nestboxes, artificial platforms and native vegetation. Private citizens and municipal employees can play fundamental roles in increasing nest site availability to birds prospecting in spaces that they either own or manage.

\section{Nest design and urbanisation}

In addition to the changes in nest sites described above, urbanisation can affect different aspects of nest design of birds. In this context, nest composition has received increasing attention recently (Table 2). Several studies have highlighted a change in nesting materials along an urbanisation gradient (e.g., Wang et al. 2009; Radhamany et al. 2016; Reynolds et al. 2016), while others did not find such effects (e.g., Townsend and Barker 2014; Hanmer et al. 2017), suggesting that nest design may exhibit species-specific or even city-specific differences. It is also possible that the latter studies failed to find changes in nest composition because they considered too small a variation in human activities along their urbanisation gradient by including urban and intensively agricultural areas but not natural areas for comparisons. The main changes in nest composition are associated with an increased use of anthropogenic nesting materials and a reduction in natural materials, especially native plants (Wang et al. 2009; Radhamany et al. 2016). Increased use of other components such as feathers as nesting materials have also been described (e.g., Reynolds et al. 2016).

Several hypotheses have been proposed to explain these changes in nest composition. Some authors argue that the main cause is the reduction in native plants (and plant material in general) in addition to the higher availability of other anthropogenic materials (e.g., plastics) in urban areas (Wang et al. 2009). This 'availability hypothesis' assumes that birds simply select the materials most widely available, with no adaptive value of such changes, and is supported by the fact that nest composition varies according to the local availability of nesting materials (Wimberger 1984), including those that are anthropogenic (Jagiello et al. 2018). Interestingly, Black-faced Spoonbills (Platalea minor) reduced anthropogenic materials in their nests when supplied with natural elements in their nest surroundings (Lee et al. 2015), suggesting that cities might provide suboptimal nesting materials for birds. The abundance of certain plants (e.g., pines [Pinus spp.]) in the city of Montpellier, France is also linked to the use of pine needles by urban Great Tits, a nesting material not used by populations in non-urban locations (Lambrechts et al. 2017), supporting this hypothesis as well. A second idea (the 'age hypothesis') would suggest that urban-associated changes in nest composition might be due to cities being inhabited by older birds (e.g., Evans et al. 2009b; Ibáñez-Álamo et al. 2018) and the increasing use of anthropogenic nesting materials with age in some species (Sergio et al. 2011; Jagiello et al. 2018). The causes of this association between age of breeder and use of anthropogenic nesting materials are unclear, but it is likely that previous experience in the habitat plays a role. This supports predictions from the age hypothesis that urban birds are older due 
Table 2 Details of studies (by continent) that have investigated nest design of urban bird species

\begin{tabular}{|c|c|c|c|c|c|c|c|}
\hline Continent & Species name & Study type & $\begin{array}{l}\text { Part of nest } \\
\text { studied }\end{array}$ & $\begin{array}{l}\text { Anthropogenic } \\
\text { nesting mate- } \\
\text { rial? } \\
(\mathrm{Y}-\mathrm{Yes} ; \mathrm{N}-\mathrm{No})\end{array}$ & Nest type & Nest site & Source \\
\hline \multirow[t]{17}{*}{ Asia } & $\begin{array}{l}\text { Baya Weaver } \\
\text { (Ploceus philip- } \\
\text { pinus) }\end{array}$ & Observational & No distinction & $\mathrm{N}$ & Dome & Native vegetation & Sohi and Kler 2017 \\
\hline & $\begin{array}{l}\text { Common Myna } \\
\text { (Acridotheres } \\
\text { tristis) }\end{array}$ & Observational & No distinction & $\mathrm{Y}$ & Cavity & $\begin{array}{l}\text { Native veg- } \\
\text { etation, houses, } \\
\text { anthropogenic } \\
\text { structures }\end{array}$ & Sohi and Kler 2017 \\
\hline & $\begin{array}{l}\text { Common Pigeon } \\
(\text { Columba livia })\end{array}$ & Observational & No distinction & $\mathrm{Y}$ & Open & $\begin{array}{l}\text { Houses, uninhab- } \\
\text { ited buildings, } \\
\text { anthropogenic } \\
\text { structures }\end{array}$ & Sohi and Kler 2017 \\
\hline & $\begin{array}{l}\text { Common Swift } \\
\text { (Apus apus) }\end{array}$ & Observational & No distinction & $\mathrm{N}$ & Hole & Houses & Sohi and Kler 2017 \\
\hline & $\begin{array}{l}\text { Cattle Egret } \\
\quad \text { (Bubulcus ibis) }\end{array}$ & Observational & No distinction & $\mathrm{Y}$ & Open & Native vegetation & Sohi and Kler 2017 \\
\hline & $\begin{array}{l}\text { Eurasian Collared } \\
\text { Dove (Streptope- } \\
\text { lia decaocto) }\end{array}$ & Observational & No distinction & $\mathrm{Y}$ & Open & $\begin{array}{l}\text { Native vegetation, } \\
\text { houses }\end{array}$ & Sohi and Kler 2017 \\
\hline & $\begin{array}{l}\text { House Crow (Cor- } \\
\text { vus splendens) }\end{array}$ & Observational & No distinction & $\mathrm{Y}$ & Open & Nestbox & Sohi and Kler 2017 \\
\hline & $\begin{array}{l}\text { House Sparrow } \\
\text { (Passer domes- } \\
\text { ticus) }\end{array}$ & Observational & Lining & $\mathrm{Y}$ & Hole & Not specified & $\begin{array}{l}\text { Radhamany et al. } \\
2016\end{array}$ \\
\hline & House Sparrow & Observational & No distinction & $\mathrm{Y}$ & Hole & Not specified & Sohi and Kler 2017 \\
\hline & $\begin{array}{l}\text { Light-vented Bul- } \\
\text { bul (Pycnonotus } \\
\text { sinensis) }\end{array}$ & Observational & No distinction & $\mathrm{Y}$ & Open & Not specified & Wang et al. 2009 \\
\hline & $\begin{array}{l}\text { Pied Myna (Stur- } \\
\text { nus contra) }\end{array}$ & Observational & No distinction & $\mathrm{Y}$ & Dome & $\begin{array}{l}\text { Native vegetation, } \\
\text { anthropogenic } \\
\text { structures }\end{array}$ & Sohi and Kler 2017 \\
\hline & $\begin{array}{l}\text { Purple Sunbird } \\
\text { (Cinnyris asiati- } \\
\text { cus) }\end{array}$ & Observational & No distinction & $\mathrm{Y}$ & Dome & Native vegetation & Sohi and Kler 2017 \\
\hline & $\begin{array}{l}\text { Red-vented Bulbul } \\
\text { (Pycnonotus } \\
\text { cafer) }\end{array}$ & Observational & No distinction & $\mathrm{Y}$ & Open & Native vegetation & Sohi and Kler 2017 \\
\hline & $\begin{array}{l}\text { Red-wattled Lap- } \\
\text { wing (Vanellus } \\
\text { indicus) }\end{array}$ & Observational & No distinction & $\mathrm{N}$ & Open & Ground & Sohi and Kler 2017 \\
\hline & $\begin{array}{l}\text { Rose-ringed Para- } \\
\text { keet (Psittacula } \\
\text { krameri) }\end{array}$ & Observational & No distinction & Not specified & Hole & Native vegetation & Sohi and Kler 2017 \\
\hline & $\begin{array}{l}\text { Scaly-breasted } \\
\text { Munia (Lon- } \\
\text { chura punctu- } \\
\text { lata) }\end{array}$ & Observational & No distinction & $\mathrm{Y}$ & Dome & Native vegetation & Sohi and Kler 2017 \\
\hline & $\begin{array}{l}\text { Wire-tailed Swal- } \\
\text { low (Hirundo } \\
\text { smithii) }\end{array}$ & Observational & No distinction & $\mathrm{N}$ & Hole & Houses & Sohi and Kler 2017 \\
\hline \multirow[t]{2}{*}{ Europe } & $\begin{array}{l}\text { Blue Tit } \\
\text { (Cyanistes caer- } \\
\text { uleus) }\end{array}$ & Observational & $\begin{array}{l}\text { Nest base and } \\
\text { lining }\end{array}$ & $\mathrm{Y}$ & Hole & Nestbox & $\begin{array}{l}\text { Reynolds et al. } \\
2016\end{array}$ \\
\hline & Blue Tit & Observational & No distinction & $\mathrm{Y}$ & Hole & Nestbox & Hanmer et al. 2017 \\
\hline
\end{tabular}


Table 2 (continued)

\begin{tabular}{|c|c|c|c|c|c|c|c|}
\hline Continent & Species name & Study type & $\begin{array}{l}\text { Part of nest } \\
\text { studied }\end{array}$ & $\begin{array}{l}\text { Anthropogenic } \\
\text { nesting mate- } \\
\text { rial? } \\
(\mathrm{Y}-\mathrm{Yes} ; \mathrm{N}-\mathrm{No})\end{array}$ & Nest type & Nest site & Source \\
\hline & $\begin{array}{l}\text { Great Tit (Parus } \\
\text { major) }\end{array}$ & Observational & No distinction & $\mathrm{Y}$ & Hole & Nestbox & Hanmer et al. 2017 \\
\hline & Great Tit & Observational & No distinction & $\mathrm{N}$ & Hole & Nestbox & $\begin{array}{l}\text { Lambrechts et al. } \\
2017\end{array}$ \\
\hline \multirow[t]{4}{*}{ North America } & $\begin{array}{l}\text { American Crow } \\
\text { (Corvus brachy- } \\
\text { rhynchos) }\end{array}$ & Observational & No distinction & $\mathrm{Y}$ & Open & Not specified & $\begin{array}{c}\text { Townsend and } \\
\text { Barker } 2014\end{array}$ \\
\hline & $\begin{array}{l}\text { House Finch } \\
\text { (Haemorhous } \\
\text { mexicanus) }\end{array}$ & Observational & Lining & $\mathrm{Y}$ & Open & Not specified & $\begin{array}{l}\text { Suárez-Rodríguez } \\
\text { et al. 2013, } 2017\end{array}$ \\
\hline & House Finch & Experimental & Lining & $\mathrm{Y}$ & Open & Not specified & $\begin{array}{l}\text { Suárez-Rodríguez } \\
\text { and Macías Gar- } \\
\text { cia } 2014,2017\end{array}$ \\
\hline & House Sparrow & Observational & Lining & $\mathrm{Y}$ & Hole & Not specified & $\begin{array}{r}\text { Suárez-Rodríguez } \\
\text { et al. 2013, } 2017\end{array}$ \\
\hline
\end{tabular}

to their higher survival rates compared to conspecifics in rural areas, as opposed to older birds dispersing to cities from natural or rural habitats, although these possibilities remain to be tested experimentally. The availability and age hypotheses assume that anthropogenic materials are used because of their resemblance to naturally occurring nesting materials (Antczak et al. 2010; Townsend and Barker 2014; Biddle et al. 2018), although there has been no direct test of this assumption. Additionally, the 'new location hypothesis' proposes that such changes in nest composition are driven by changes imposed by the locations of nest sites in new areas (Reynolds et al. 2016). In contrast to predictions from the availability hypothesis, urban birds would change their nesting materials as a consequence of using alternative (new) nest sites that impose different requirements. Some authors have raised concerns over the potential bias associated with the use of nestboxes when investigating factors such as nest ectoparasite exposure, anti-predator defences and constraining size limitations of the nest substrate (Wesołowski and Stanska 2001; Wesołowski 2011). The comprehensive use of nestboxes to study birds in many cities compared with studies of birds in natural nesting habitats, and the potential link between some of these nestbox traits and nest composition, lend support to the new location hypothesis. Other urban-associated changes in nest sites like those undertaken by Common Blackbirds (Turdus merula) nesting on window canopies or balcony frames rather than in vegetation in China (Wang et al. 2015) and Europe (JD Ibáñez-Álamo pers obs), or by Eurasian Magpies (Pica pica) nesting on chimneys and roofs instead of trees in the city of Hangzhou, China (Wang et al. 2008), might also indicate that modifications to nest composition that allow for secure attachment of nests to substrate are not insurmountable for urban birds.
Finally, the 'adaptive hypothesis' assumes that changes to nest design are driven by their adaptive value. The strongest support for this hypothesis is provided by research demonstrating that some urban species actively use smoked cigarette butts for self-medication. Through a series of manipulative and observational studies, researchers were able to prove that the use of cigarette butts by a common Mexican urban species, the House Finch (Haemorhous mexicanus), fulfils all three of the characteristics of self-medication behaviour as described by Clayton and Wolfe (1993): (1) they are detrimental to parasites (Suárez-Rodríguez et al. 2013), (2) they are actively selected by birds (Suárez-Rodríguez and Macías Garcia 2017), and (3) they increase their fledging success (Suárez-Rodríguez and Macías Garcia 2014). The use of cigarette butts is not just restricted to House Finches in Mexico (Suárez-Rodríguez and Macías Garcia 2017), and has been found in other species such as House Sparrows in North America (Suárez-Rodríguez et al. 2013, 2017) and Asia (Radhamany et al. 2016), suggesting that it might be a general behavioural innovation for urban-adapted species. In contrast, Blue Tits (Cyanistes caeruleus), a species that does not use cigarette butts as nest constituents, in the town of Reading, UK using more anthropogenic nesting material had larger numbers of fleas (Siphonaptera) within their nest contents (Hanmer et al. 2017). The authors argue that this is caused by a reduction in the diversity of nest-dwelling arthropods (including potential competitors and predators of flea larvae). Overall, these studies suggest that the potential adaptive value of changes in nest composition might depend on the relative availability and properties (e.g., antimicrobial) of anthropogenic nesting materials within breeding habitats. 
The anti-parasitic function is not the only adaptive function that can be performed by anthropogenic nesting materials used by birds breeding in cities (Mainwaring et al. 2014b). Some of this can perform a signalling function. For example, plastics in nests of Black Kites (Milvus migrans) may be involved in intraspecific signalling, as they can provide information about the nest owner's 'quality' (Sergio et al. 2011). Anthropogenic nesting materials are also used in sexual selection by bowerbirds (Ptilonorhynchidae) (e.g., Borgia 1985). Interestingly, the visual component of cigarette butts does not appear to perform this function in Song Thrushes (Turdus philomelos), although it might play a part as an olfactory signalling component (Igic et al. 2009). However, these ideas about signalling remain untested in urban birds and require further investigation before associating it with the urbanisation process. The only link between this signalling function and urbanisation so far has been made to explain changes in the number of feathers along an urbanisation gradient in Blue Tit nests from the city of Birmingham, UK (Reynolds et al. 2016). This is based on the idea that feathers may signal intrusions into nests by competitors (Mainwaring et al. 2016) and that density of birds can change as a result of urbanisation (Evans 2010). Although only suggestive, such changes in nest design might also occur in response to changes in sexual selection (Sanz and García-Navas 2011) or microbial loads (PeraltaSánchez et al. 2010; Ruiz-Castellano et al. 2016) along the urbanisation gradient, and therefore will require further studies before reaching firm conclusions. Changes in the thermal properties of nests could also explain variation in nest composition along the urbanisation gradient if, for example, anthropogenic and natural materials have different insulating properties. Cities contain urban heat islands where ambient temperature can be a few degrees Celsius higher than in non-urban areas (Oke 1982; Forman 2014). However, this thermal urban phenomenon has not been explored in the context of nest design, although the improvement of nest microclimate has been proposed to explain the use of certain anthropogenic materials as nest components (Igic et al. 2009). Finally, nesting materials can also play an important role in avoiding nest predation (Mainwaring et al. 2015). In fact, it has also been suggested that some anthropogenic materials such as cigarette butts might have anti-predatory functions, potentially deterring odour-driven predators (Igic et al. 2009), but this idea has not been investigated to date.

Despite the potential benefits, changes in nest composition associated with urbanisation might translate into costs incurred by the avian constructor. The use of cigarette butts, for example, imposed costs on both nestlings and adult birds that experienced higher genotoxic damage, possibly because of the many toxic substances contained in cigarettes (Suárez-Rodríguez and Macías Garcia 2014; Suárez-Rodríguez et al. 2017). Interestingly, this damage occurred only in the sex(es) that participated in nest building, indicating that costs incurred may be sex-specific according to parental roles (Suárez-Rodríguez et al. 2017). Whether this damage implies long-term or even fertility costs is not known, but it will be crucial to identify the net fitness balance of the use of cigarette butts and potentially other novel nesting materials in the urban environment. Other studies have demonstrated that anthropogenic nesting materials (e.g., plastic twine, fishing line or metal pieces) in the nests of several species are associated with an increased frequency of nestling deaths from entanglement, strangulation and other injuries (Blem et al. 2002; Parker and Blomme 2007; Antczak et al. 2010; Henry et al. 2011; Townsend and Barker 2014).

Within a cost-benefit context, we believe that mechanistic studies offer some of the best ways to understand trade-offs faced by breeding urban birds. This is clearly exemplified by the studies of Mexican House Finches which found that cigarette butts promoted an immuno-enhancement effect and mass gain in chicks, but they also induced erythrocyte genotoxicity in nestlings and adults (Suárez-Rodríguez and Macías Garcia 2014; Suárez-Rodríguez et al. 2017). Such research provides new insights into the non-lethal effects of anthropogenic materials and potentially explains why urban areas might be ecological traps for certain avian species (Dias 1996; Leston and Rodewald 2006; Sumasgutner et al. 2014a). Similarly, they could offer much needed information to understand the positive and negative effects of urban-associated changes in nest composition. While clearly anthropogenic materials such as cigarette butts assist ectoparasite control in nests, we still lack a deep understanding of how they reduce ectoparasite loads of nests, promote changes in the arthropod community of nests and improve nestling health (Suárez-Rodríguez et al. 2013; Hanmer et al. 2017).

Nest structures are another important variable in nest design (Deeming and Reynolds 2015). According to Hansell (2000), there are four main parts/structures in nests: attachment, outer (decorative) layer, structural layer and lining. Apart from the study of Radhamany et al. (2016), investigations of how urban environments impact nest design either quantify materials without distinction (e.g., Wang et al. 2009; Sohi and Kler 2017) or are focused exclusively on changes to the nest lining (e.g., Suárez-Rodríguez et al. 2013), paying very little attention to other structures. This is probably a consequence of anthropogenic nesting materials being more commonly used as lining material, although some taxa such as thrushes (Turdidae) seem to use them as structural material as well (Biddle et al. 2016). Many turdids are among the most common urban bird species (e.g., Wang et al. 2015; Ibáñez-Álamo et al. 2017b, 2018), which makes them excellent candidate subjects for further study. 
Previous studies provide mixed support for the variation in nest size and mass in association with urbanisation. On the one hand, several authors found no variation in nest mass or size along an urbanisation gradient for Blue or Great Tits in different European cities (Glądalski et al. 2016; Reynolds et al. 2016; Lambrechts et al. 2017). On the other hand, Hanmer et al. (2017) found that Blue Tits, but not Great Tits, in the same English town had lighter nests in more urbanised areas. This could be explained in a thermal context, as several studies have found geographical variation in nest size/mass that has been attributed to variations in ambient temperature (Deeming et al. 2012; Mainwaring et al. 2012, 2014a; Biddle et al. 2016). Other constraints such as the lack of appropriate materials or new nest locations could also influence nest size and mass. Overall, this topic is clearly understudied, and future investigations should try to test these hypotheses by studying different bird species (e.g., open nesters) and in different geographical areas (e.g., highlatitude or tropical areas).

\section{Urban nesting biology and conservation}

Urbanisation is currently considered a major global challenge, not least to nature conservation (Miller and Hobbs 2002; McKinney 2006; Ibáñez-Álamo et al. 2017a). Worldwide, urban areas heavily influence the ecology of animal species through habitat loss, increased fragmentation and pollution, or communities that often contain more invasive species (Alberti et al. 2003; Grimm et al. 2008). Nevertheless, the proximity of humans to birds creates valuable opportunities for public engagement and urban conservation (Marzluff 2014). Such engagement could focus on cavitynesting species, as this is a nesting trait that appears to be shared by most successful breeders in the urban environment (Chace and Walsh 2006; Kark et al. 2007). Therefore, there is a clear opportunity to use nestboxes specifically as a conservation tool. The availability of different kinds of nestboxes may increase the colonisation of urban parks by a great variety of cavity-nesters, including threatened species (Jokimäki 1999; Jokimäki et al. 2018). Nestboxes increase breeding opportunities for urban birds, because there are fewer natural cavities or hollows in trees in urban areas than in continuous woodlands (Davis et al. 2014b); they ensure that nest sites are available in areas where they would otherwise be limiting (Schaub et al. 2015). They can, however, also be disadvantageous by acting as ecological traps (Demeyrier et al. 2016) or by being occupied by a variety of invasive species of birds (Grarock et al. 2013; Bender et al. 2016) and mammals (Harper et al. 2005). For example, although the number of Peregrine Falcon (Falco peregri$n u s$ ) pairs increased in Cape Town, South Africa at the same time as nestboxes were provided, it was immigration that drove the population increases (Altwegg et al. 2014), which illustrates more broadly that nestboxes are only useful when nest sites are in limited supply. In another study in Madrid, Spain, nestboxes were utilised not only by parids but also by other species. Tree Sparrows (Passer montanus) took over the nestboxes, constructing nests that filled the entire box, thereby rendering them inaccessible to other species looking to use them for future breeding attempts (Fernández-Juricic and Jokimäki 2001).

Despite many negative effects of urbanisation on wildlife, several threatened bird species, including critically endangered ones, inhabit urban core areas; they include White-rumped Vultures (Gyps bengalensis) in Kolkata, India, Orange-bellied Parrots (Neophema chrysogaster) in Melbourne, Australia, Spoon-billed Sandpipers (Eurynorhynchus pygmeus) and Christmas Frigatebirds (Fregata andrewsi) in Singapore, and Balearic Shearwaters (Puffnus mauretanicus) in Valencia, Spain (Aronson et al. 2014). Jokimäki et al. (2018) concluded that within European cities, most threatened species commonly nest in cavities, including House Sparrows, Common Swifts and House Martins (Delichon urbica). If a species is able to exploit opportunities such as holes and cavities in buildings for nesting while tolerating human presence, this may facilitate population growth and establishment in the novel breeding niches in cities (see review by Tomiałojć 2016). Authors including Schaub et al. (2015) suggest that modern building design should accommodate the breeding requirements of cavitynesting species. Additionally, creation and management of urban green spaces should include retention of old trees, providing cavities and/or provision of nestboxes to support breeding attempts of threatened, cavity-nesting species such as Orange-bellied Parrots in Australia (Loyn et al. 1986). While such conclusions promote conservation of urban birds, they result in other fundamental considerations such as whether human-made nest structures should be designed to exclude potential predators, and who should be responsible for their maintenance to prevent damage to buildings or injuries to the general public.

The challenges for avian conservation in cities broadly fall into two categories: (i) the amount of human interference in an already altered ecosystem, and (ii) emerging human-wildlife conflicts often encountered in urban environments where humans and other species live in close proximity to each other. As one of the most dramatically transformed, fragmented and highly disturbed habitats on Earth, species richness in urban areas is lower than in nearby natural areas (e.g., McKinney 2008; Ibáñez-Álamo et al. 2017a), and this is reflected in simplified food webs and a greater influence of bottom-up processes (Faeth et al. 2005). Many of these urban habitat features have implications for nesting birds and offer opportunities for management to improve productivity and survival. For example, 
habitat fragmentation increases the amount of edge habitat (Murcia 1995). This edge-related gradient systematically alters abiotic variables near the edge, but also affects biotic interactions (Fagan et al. 1999). The edge functions as a dispersal barrier or filter and can influence mortality or generate novel interactions (Fagan et al. 1999), as seen in birds' nests that are more likely to be parasitised by cowbirds (Molothrus spp.) when they are located near a habitat edge (Lloyd et al. 2005). Providing nesting habitat or nest sites in larger urban green patches with proportionally reduced edge habitat could reduce the frequency of brood parasitism. Another example is the Spotted Towhee (Pipilo maculatus) that prefers forest edges near residential areas in Portland, Oregon, USA, where they fledge more young compared to birds selecting nest sites in the forest interior (Shipley et al. 2013). However, nestling mortality is lower in the forest interior, owing to high predation by Domestic Cats (Felis catus) and Western Screech Owls (Megascops kennicottii) at the forest edge.

Another global characteristic of urban areas is an increase in anthropogenic disturbance and pollution that can lead to modified nest placement and creation of ecological traps as a result. For example, Black-billed Magpies (Pica hudsonia) (Wang et al. 2008) and Eurasian Magpies (Jerzak 2001) nest significantly higher above the ground with urbanisation intensity. Another example is provided by the Syrian Woodpecker (Dendrocopos syriacus) that prefers areas where pollution weakens trees and increases the abundance of barkdwelling insects inhabiting them, but where birds may be negatively impacted by air pollution itself, reducing their body condition (Ciach and Frohlich 2013). Of course, such considerations will ultimately shape conservation measures such as the placement of artificial nest sites if so desired.

Urbanisation also acts as a filter which excludes some species and changes the composition of avian communities through novel and rapid evolutionary forces (Shanahan et al. 2014). The filtering mechanism that results in avian communities we observe in urban environments is not well understood, but at its heart is also the human component itself. For example, we facilitate the breeding of many bird species in urban environments by intentionally providing supplementary food or artificial nest sites (Robb et al. 2008; Davies et al. 2009). As part of such interventions, we need to make conscious decisions about which species we are targeting (and looking to deter) and where to provide such support. Our provision of nesting habitat or artificial nest sites not only favours a limited number of species (e.g., cavity nesters that use nestboxes), but also favours species that are considered charismatic by citizens, such as small passerines and falcons (Falconidae). Contrary to this, we install deterrents such as metal pins to prevent some less favoured species such as corvids (Corvidae), pigeons and doves from nesting or even alighting on urban infrastructure. Understanding which urban species are encouraged or discouraged by our activities is fundamental before we promote conservation initiatives that require significant inputs (e.g., time, money, energy) from citizens (Toft 2014). This strikes at the heart of the emerging discipline of ethno-ornithology (Tidemann and Gosler 2010) that examines human-bird interactions through integration of traditional (TEK) and scientific ecological knowledge (SEK) bases (Cocker and Tipling 2013).

Human-wildlife conflicts emerge globally (Redpath et al. 2013) wherever humans and wildlife compete for resources, and often require wildlife management. Wildlife management is primarily a human response to reduce or eliminate causes of economic or social damage caused by wildlife (Treves et al. 2006), and conservation goals are becoming an important part of such management (Redpath et al. 2013). Urban birds are no exception. For example, urban areas are like all transformed ecosystems vulnerable to invasive species (Godefroid and Ricotta 2018). Unlike temperate areas, there is a lack of data on what kinds of decorative ornamental plants are being used in urban green areas in tropical countries (Müller et al. 2013). Native bird species diversity has been shown to decline with an increase in exotic plant species in Delhi, India (Khera et al. 2009). However, there are examples where birds profit from alien plants in urban green space, as seen in the recent colonisation of Cape Town, South Africa by Black Sparrowhawks (Accipiter melanoleucus) (Martin et al. 2014), or the Crowned Eagle (Stephanoaetus coronatus) population in Durban, South Africa (McPherson et al. 2016a) that is at higher breeding densities than those reported in natural (non-urban) habitats. Both raptor populations nest in exotic pine (Pinus spp.) and eucalyptus trees (Eucalyptus spp., Malan and Robinson 2001; Tarboton 2001; Malan and Shultz 2002) that are currently the subjects of invasive plant removal. Invasive eucalyptus species are targeted (i.e., killed by ring-barking) by a government-funded nationwide management scheme called 'Working for Water' that aims primarily to provide poverty relief by employing task forces to control invasive vegetation and restore indigenous hydrological systems (Forsyth et al. 2004; Turpie et al. 2008). These dead trees stand defoliated and decaying for many years, resulting in a less sheltered nest site that will ultimately disappear. Therefore, conservation goals are in conflict (Dickie et al. 2014), which might affect other species such as African Fish-Eagles (Haliaeetus vocifer) in the Western Cape of South Africa, where eucalyptus trees provide the only suitable nesting source (Welz and Jenkins 2005). Such invasive plant removal is an area of conflict in many urban systems, particularly where they provide habitat or food for wildlife and where they affect animal taxa of high charismatic value such as birds and butterflies (Dickie et al. 2014). Further examples include the removal of invasive tamarisk (Tamarix spp.) in the USA that conflicts with conservation efforts targeting Willow 
Flycatchers (Empidonax traillii), an endangered species that uses invasive trees for nesting (Shafroth et al. 2008; Schlaepfer et al. 2011), and the removal of Monterey Pine (Pinus radiata) plantations near Perth, Australia, that might result in declines in Short-billed Black Cockatoos (Calyptorhynchus latirostris) (Finn et al. 2009).

Direct conflicts can emerge between birds and humans, with one of the best-known examples being Australian Brushturkeys (Alectura lathami) that construct massive incubation mounds from up to 4 tonnes of leaf litter, causing a clear conflict with garden owners, although many people welcome the species (Jones and Everding 1991). Australian Magpies (Gymnorhina tibicen) are an urban nesting species that exhibits extraordinary levels of aggression as they defend nest sites, attacking human intruders and causing injuries (Jones 2008). Another example is provided by parakeets (Psittacula spp.) nesting in towns and cities of Europe (Strubbe and Matthysen 2009). Rose-ringed Parakeets (Psittacula krameri) are secondary cavity-nesters and compete with native species (Strubbe and Matthysen 2007, 2009). The bulky communal nests of Monk Parakeets (Myiopsitta monachus) are known to cause damage to human infrastructure (Avery and Shiels 2017). Public stakeholders in an urban landscape have a strong influence on the management of dangerous large animals such as carnivores (Treves et al. 2006; Gehrt et al. 2010; Poessel et al. 2012). Likewise, one such avian example is provided by Crowned Eagles in the urban landscapes of southern KwaZulu-Natal, South Africa (McPherson et al. 2016a). They have occasionally been reported to prey upon livestock and pets (Boshoff 1990; Boshoff et al. 1994; McPherson et al. 2016b), with 24 verified attacks on Domestic Dogs (Canis lupus familiaris) documented between 2012 and 2017 in Durban and Pietermaritzburg (SC McPherson, pers comm). Crowned Eagles build huge nests that occasionally collapse, and artificial nest platforms have been used to replace such collapsed nest structures (Hoffman and Hoffman 2009). The placement of such artificial platforms becomes critically important in reducing conflicts between urban birds and their attacks directed at companion animals of urban residents.

While humans act as filters for avifauna within our cities through provisioning of food or nest sites, the ethics of such human behaviour have not been questioned in depth. Of course, interventions such as the provision of artificial nest sites (e.g.. nestboxes, platforms) are important for the conservation of urban birds because even if they do not necessarily increase population density of a species, they promote our more intimate experiences of breeding birds (Fuller et al. 2012; Lepczyk et al. 2012). Public engagement increases awareness that is known to be a powerful tool in nature conservation (Devictor et al. 2010).

\section{Future research addressing the nesting biology of urban species}

There are many areas of research of urban nesting biology that deserve further attention, as we outline below. However, discussions about urban breeding birds are often dominated by the concept of the ecological trap. Therefore, we start this section by making some pertinent comments about future research concentrating on this concept. Maladaptive habitat occupation decision-making implies a preference for low-quality habitats over high-quality options, which can occur in heavily transformed habitats such as urban environments (e.g.. Demeyrier et al. 2016). Such maladaptive behaviour causes species to fall into socalled ecological traps (reviewed in Kokko and Sutherland 2001; Schlaepfer et al. 2002; Kristan 2003; Battin 2004; Robertson and Hutto 2006). It is important to distinguish between an ecological trap and a habitat sink (see Kristan 2003). An ecological trap may have no population-level consequences (Robertson and Hutto 2006), but if organisms therein encounter adverse effects that result in the resident population not being self-sustaining, the area is instead described as a 'habitat sink' (Donovan and Thompson 2001). We use the term 'ecological trap' throughout this paper in accordance with the above distinction: a maladaptive behaviour displayed by a bird that does not necessarily result in population-level negative effects such as productivity being insufficient to offset mortality.

In regard to nest sites, there are four research areas that deserve attention. First, whilst there is good evidence that many bird species use native and non-native trees and shrubs, as well as a variety of anthropogenic structures as nest sites, we do not actually know whether such nest sites or nesting materials are in limited supply for birds in urban areas. Determining whether nest sites or nesting materials are limiting, especially for those species that predominantly avoid urban areas but that we may wish to target for conservation in urban areas, is important because, if limiting, future research might examine ways to improve urban nesting conditions in urban environments for such species, thereby promoting urban biodiversity conservation. Competition for nest sites and the effectiveness of measures to restore breeding habitat should thus be experimentally assessed before setting up any management measures for every target species. Currently, we are unsure whether the provisioning of artificial nest sites such as nestboxes or nest platforms reflects availability of natural nest substrates in the same urban habitats. Whereas the latter are permanent (as long as they remain accessible to birds) features of the urban landscape, artificial nest sites have to be maintained, the timing of which needs to be carefully orchestrated to minimise disturbance to urban birds. Therefore, studies that 
examine the population status of urban bird communities before and after nest sites have been either experimentally or inadvertently provided or removed would enable us to examine whether availability of nest sites is limiting. This should be extended to broaden geographical coverage in answering such a fundamental question about nest site availability, because the abundance of cavity-nesting bird species increased in North America (Chace and Walsh 2006) but decreased in Australia (Luck and Smallbone 2010) with increasing levels of urbanisation. Patterns of nest site limitation may well vary between species with, for example, the provision of nestboxes with small entrance holes overwhelmingly promoting occupation by parids but deterring heavier and bigger species such as Western Jackdaws (Corvus monedula) from nesting.

Secondly, urban areas are considered to contain fragmented habitats because suitable nesting areas are usually separated by intensive land use such as transport infrastructure or buildings (Marzluff and Ewing 2001). Although isolation of such nesting habitat appears not to exclude most volant species in principle, in practice behavioural inhibition may preclude some species from nesting in such areas (Møller 2010), and certainly this should be investigated further. Moreover, habitat fragmentation may reduce the breeding success of at least some species. Marzluff and Ewing (2001) found that nest predators such as mammals, corvids and raptors thrive in urban areas where nests of native bird species are exposed to increased predation risk by virtue of being nearer to fragmented habitat edges where such predators patrol. Habitat fragmentation may also increase the time and energy needed to search for suitable nesting materials, and so further studies could usefully examine the nest-building behaviours of birds in urban versus non-urban areas.

Thirdly, the overwhelming majority of research examining the use of nest sites in urban areas has focused on birds in large cities (and conurbations), with far less research performed in smaller towns and cities. Therefore, future research could usefully examine the availability and use of nest sites in smaller urban centres, where temporal and energetic investment in searching for natural foods or nesting materials could be significantly reduced compared with birds breeding within dense urban matrices. Such research will help to increase our understanding of the importance of the configuration and size of habitat types to urban-adapted bird species.

Fourth, nestboxes and other artificial nest sites are widely provided for urban birds in North America and Europe, but we know very little about their value to birds. There is good evidence that building cavities and nestboxes act as ecological traps for birds in urban areas (Sumasgutner et al. 2014a; Demeyrier et al. 2016), but future research should test the generality of this effect. Furthermore, nestbox provision by humans varies considerably by geographic region, and future research could examine the utilitarian value of provision of artificial nest sites in light of prevailing nesting conditions. For example, birds in non-temperate areas such as arid areas may use bushes or ground holes more commonly than in temperate regions. Furthermore, in tropical areas, the diversity of nest sites could be so high that green spaces such as parks within cities should be managed differently from those in temperate zones so that, for example, many more shrubs should be planted and maintained in those green spaces. Ultimately, future research in these areas will provide valuable insights into the influence of the native habitat on urban bird assemblages.

With regard to nest design, future studies should prioritise the following areas. From a methodological point of view, there are five important aspects that should be highlighted. First, it will be important to define more precisely what we mean by 'anthropogenic nesting materials'. While it is common to include man-made materials only (e.g., plastics, fishing line, cloth) in this category of nesting materials (e.g., Wang et al. 2009; Sohi and Kler 2017; Biddle et al. 2018), it has been suggested that we might include other material associated with human activities such as hair from livestock and companion animals that we associate with, or materials from ornamental plants that we introduce into our urban gardens (Hanmer et al. 2017). Secondly, urban nest studies seldom employ state-of-the-art technology that is commonplace in other strands of field ornithology. We argue that the use of miniaturised, high-resolution wireless cameras to film nest-building behaviour (Ribic et al. 2012), biotelemetry to follow adult activities during the nest-building stage, and self-contained thermal monitoring units (Smith et al. 2015) to study incubation patterns at the nest will allow testing of some of the hypotheses addressing urban nest design. Thirdly, we need information from more species, particularly those exhibiting different nesting traits (e.g., use of ornamental layers), and from different regions of the world (e.g., South America, Australia/Oceania or Africa) where basic information about nest design is rudimentary at best (Table 2). Biddle et al. (2018) found evidence for interspecific variation in the use of anthropogenic material in different parts of nests, highlighting the importance of comparison when studying the effects of urbanisation on nest design (e.g., nest composition). Fourth, we need to perform more experimental studies, particularly to investigate the thermal ecology and humidity of birds' nests and how they relate to breeding performance. Standardised methods should be used in all such future studies, as recently advocated for the incorporation of anthropogenic materials into birds' nests by Provencher et al. (2017). While basic information about nest design in urban areas (especially regarding nest structures, ornaments and attachments) is desirable, if we want to understand how nest design varies with the urban landscape, we require landscape features (e.g., substrate, nesting 
material availability) to be manipulated directly by researchers. Finally, following on from the successes of citizen science nest projects run by agencies in the UK [i.e., the British Trust for Ornithology's Nest Record Scheme (NRS)] and the USA (Cornell Lab of Ornithology's NestWatch project), we believe that there remains great potential for citizen scientists to contribute to our knowledge of nest design of urban birds (Greenwood 2007; Cooper 2017). We challenge other countries to engage with their citizen scientists to this end.

From a conceptual point of view, there are also several important ideas to consider in future studies. First, we need to investigate further whether the urban-associated changes in nest design translate into fitness consequences for the avian builders, focusing on both benefits and costs to them. This is crucial to understanding whether such changes are adaptive, facilitating urban colonisation. For example (experimental) studies that investigate whether there is a relationship between the use of anthropogenic nesting materials and fitness components such as breeding success or longevity would be very useful. A long-term perspective would be particularly important in such research, because some fitness costs might not be detectable from short-term studies (Suárez-Rodríguez and Macías Garcia 2014).

Secondly, even though it remains to be tested, it is possible that different parts/layers of nests are influenced by different selective pressures in the urban environment, their fitness consequences for nesting birds could be different, and they might not be evenly responsive across urban gradients. Unfortunately, our current knowledge of nest components other than the lining layer is very scarce. However, there is evidence to suggest that urbanisation affects more than just the nest lining. For instance, urban-associated changes in nest location for several species (see above) suggest that components responsible for attachment of the nest to its substrate may be labile in urban birds. The outer (decorative) layer could also be affected by urbanisation due to the availability of certain materials in cities or changes in selective forces (e.g., nest predation, sexual selection). An interesting, yet unexplored, idea within this context is the potential role that structural changes in urban nests might have in attenuating some common problems in cities such as noise or light pollution.

Thirdly, common urban anthropogenic materials such as plastic and string can be harder to break or isolate as nesting material compared with natural materials (e.g., grass, moss), but we know very little about their manipulation by, and their costs (e.g., increased nest detectability by parasites or predators) to, avian builders. Similarly, our understanding of the selection of anthropogenic nesting materials is scarce. For example, we know little about whether birds select them based on size, weight or other characteristics, and the sensory modalities they employ to do so.
Fourth, our understanding from a mechanistic standpoint lags behind other strands of knowledge. For example, even in the case of regulation of ectoparasites in urban bird nests, we do not understand the mechanism of action of nest composition changes that could be explained by multiple non-mutually exclusive hypotheses (Suárez-Rodríguez et al. 2013; Hanmer et al. 2017). This mechanistic link is even less detailed regarding other functions, and should be a major objective of future studies. Furthermore, as in the case of the Mexican House Finches that use cigarette butts (SuárezRodríguez et al. 2013), a mechanistic point of view will also help to uncover potential physiological costs of changes in nesting biology followed by urban birds.

Finally, beyond our focus on arthropods, we should investigate the relationship of urban birds with other nest-dwelling biota such as bacteria or fungi. Relationships between microorganisms and many higher vertebrates including birds (McFall-Ngai et al. 2013; Colston and Jackson 2016) are profound, and are particularly important in the nest environment, where they can influence avian fitness (Cook et al. 2005; Grond et al. 2018; Peralta-Sánchez et al. 2018). Some studies have examined nesting materials and avian microbiota (e.g., Mainwaring et al. 2014b; Ruiz-Castellano et al. 2016) and suggested that this microbiological perspective could help us to unveil new effects of urban-associated changes in nest design.

Overall, the research gaps outlined regarding urban nest sites and urban nest design have important implications for conservation. First, the use of nestboxes has much potential as a conservation tool, but only if we possess knowledge of the fitness consequences of breeding inside nestboxes as opposed to alternative nest sites. This information is crucial for designing successful conservation plans for target species. The case of Common Kestrels (Falco tinnunculus) provides a good example of problems that arise from a lack of appropriate knowledge. This species is considered locally threatened (Jokimäki et al. 2018), but in inner-city areas the provision of nestboxes seems to act as an ecological trap for birds (Kettel et al. 2018), as they provide nest sites (Sumasgutner et al. 2014a) that attract birds into areas not offering sufficient diurnal rodents as prey (Sumasgutner et al. 2014b).

Secondly, little is known about the availability of different nesting materials in the urban environment and the fitness consequences of using anthropogenic versus natural nesting materials (see above). However, the association between plants in cities and nest composition (Lambrechts et al. 2017), as well as a recent experiment showing that providing natural nesting materials could reduce the amount of debris incorporated into nests (Lee et al. 2015), reveals a new way of promoting urban bird conservation. This will include promoting ornamental plants that provide natural nesting materials, or the direct provisioning of natural 
nesting materials, if their shortage in cities represents a constraint for breeding birds.

Thirdly, bird nests might be useful indicators of environmental pollution (Furness and Greenwood 1993). For example, a positive relationship has been observed between the amount of debris in the area surrounding White Stork (Ciconia ciconia) nests, and that constituting the structure of the nests themselves (Jagiello et al. 2018). However, such an index of environmental pollution would need to be restricted to those bioindicator species that use nesting material in proportion to its availability in the environment, as opposed to birds that were actively selecting specific materials.

Urban avian conservation is an interdisciplinary field that requires several stakeholders to work together (Norris and Pain 2002; Greenwood 2007). This will not be an easy task, but the close association between humans and birds in these anthropogenic habitats provides exciting opportunities for research and conservation. We hope that this review shows that studying this overlooked aspect of avian biology can be very fruitful for expanding both our basic and applied ornithological knowledge.

Acknowledgements SJR would like to thank his undergraduate (Connor Barnes, Clare Davies, Emily Elwell, Corrie Grafton, Jacob Haddon, Claire Herlihy, Derek Law, Eleanor Leanne, Holly Mynott, Penny-Serena Pratt, Anna Smith, Peter Tasker, Alison Wildgoose, Amy Williams and Daniel Woodward) and postgraduate (Richard Bufton, Dan Hunt, Victoria Pattison-Willits and Jen Smith) 'nest' students, and Charles Deeming, who have all provided new insights about urban nests over the last few years. MCM thanks Charles Deeming, Tom Martin, Bret Tobalske and Blair Wolf for useful discussions on the topic of urban nesting birds. PS would like to thank the participants of the 'HumanRaptor Interactions-From Conservation Priorities to Conflict Mitigation' symposium, Arjun Amar, Daniel Berkowic, Shane McPherson and Steve Redpath for the useful discussions on the topic of urban conservation regarding human-wildlife conflicts. JDI-Á would like to thank Olivia Sanllorente for providing interesting discussions on the topic and her constant support. Finally, we all thank Dan Chamberlain and an anonymous reviewer for helpful comments that improved the manuscript significantly.

Open Access This article is distributed under the terms of the Creative Commons Attribution 4.0 International License (http://creativeco mmons.org/licenses/by/4.0/), which permits unrestricted use, distribution, and reproduction in any medium, provided you give appropriate credit to the original author(s) and the source, provide a link to the Creative Commons license, and indicate if changes were made.

\section{References}

Alberti M, Marzluff JM, Shulenberger E, Bradley G, Ryan C, Zumbrunnen C (2003) Integrating humans into ecology: opportunities and challenges for studying urban ecosystems. BioScience 53:11691179. https://doi.org/10.1641/0006-3568(2003)053\%5b116 9:ihieoa\%5d2.0.co;2

Altwegg R, Jenkins A, Abadi F (2014) Nestboxes and immigration drive the growth of an urban Peregrine Falcon Falco peregrinus population. Ibis 156:107-115. https://doi.org/10.1111/ibi.12125
Antczak M, Hromada M, Czechowski P, Tabor J, Zabłocki P, Grzybek J, Tryjanowski P (2010) A new material for old solutions-the case of plastic string used in Great Grey Shrike nests. Acta Ethol 13:87-91. https://doi.org/10.1007/s10211-010-0077-2

Aronson MFJ, La Sorte FA, Nilon CH, Katti M, Goddard MA, Lepczyk CA, Warren PS, Williams NSG, Cilliers S, Clarkson B, Dobbs C, Dolan R, Hedblom M, Klotz S, Kooijmans JL, Kühn I, MacGregor-Fors I, McDonnell M, Mörtberg U, Pryšek P, Siebert S, Sushinsky J, Werner P, Winter M (2014) A global analysis of the impacts of urbanization on bird and plant diversity reveals key anthropogenic drivers. Proc R Soc B 281:20133330. https:// doi.org/10.1098/rspb.2013.3330

Avery M, Shiels AB (2017) Monk and Rose-Ringed Parakeets. In: Pitt WC, Beasley JC, Witmer GW (eds) Ecology and management of terrestrial vertebrate invasive species in the United States. CRC Press, Boca Raton, pp 333-357

Battin J (2004) When good animals love bad habitats: ecological traps and the conservation of animal populations. Conserv Biol 18:1482-1491. https://doi.org/10.1111/j.1523-1739.2004.00417 . $\mathrm{X}$

Bender J, Fidino M, Limbrick K, Magle S (2016) Assessing nest success of Black-capped Chickadees (Poecile atricapillus) in an urban landscape using artificial cavities. Wilson J Ornithol 128:425-429. https://doi.org/10.3184/175815618x1522231875 5467

Biddle LE, Goodman AM, Deeming DC (2016) Geographical effects on the mass and dimensions of finch (Fringillidae, Passeriformes) and thrush (Turdidae, Passeriformes) nests. Avian Biol Res 9:1321. https://doi.org/10.3184/175815516x14490632108472

Biddle LE, Broughton RE, Goodman AM, Deeming DC (2018) Composition of bird nests is a species-specific characteristic. Avian Biol Res 11:132-153. https://doi.org/10.3184/175815618x15222 318755467

Bird DM, Varland DE, Negro JJ (1996) Raptors in human landscapes: adaptations to built and cultivated environments. Academic Press, London

Birkhead TR (2015) Foreword. In: Deeming DC, Reynolds SJ (eds) Nests, eggs, \& incubation: new ideas about avian reproduction. Oxford University Press, Oxford, $\mathrm{p}$ vii

Blem CR, Blem LB, Harmata PJ (2002) Twine causes significant mortality in nestling ospreys. Wilson Bull 114:528-529. https://doi. org/10.1676/0043-5643(2002)114\%5b0528:tcsmin\%5d2.0.co;2

Borgia G (1985) Bower quality, number of decorations and mating success of male satin bowerbirds (Ptilonorhynchus violaceus): an experimental analysis. Anim Behav 33:266-271. https://doi. org/10.1016/s0003-3472(85)80140-8

Borgmann KL, Rodewald AD (2004) Nest predation in an urbanizing landscape: the role of exotic shrubs. Ecol Appl 14:1757-1765. https://doi.org/10.1890/03-5129

Boshoff AF (1990) On hungry eagles and domestic pets. Birding South Africa 42:3

Boshoff AF, Palmer NG, Vernon CJ, Avery G (1994) Comparison of the diet of crowned eagles in the savanna and forest biomes of south-eastern South Africa. S Afr J Wildl Res 24:26-31

Brown CR, Brown MB (2013) Where has all the road kill gone? Curr Biol 23:R233-R234. https://doi.org/10.1016/j.cub.2013.02.023

Chace JF, Walsh JJ (2006) Urban effects on native avifauna: a review. Landsc Urban Plan 74:46-69. https://doi.org/10.1016/j.landu rbplan.2004.08.007

Chamberlain DE, Cannon AR, Toms MP, Leech DI, Hatchwell BJ, Gaston KJ (2009) Avian productivity in urban landscapes: a review and meta-analysis. Ibis 151:1-18. https://doi.org/10.1111/ j.1474-919x.2008.00899.x

Ciach M, Frohlich A (2013) Habitat preferences of the Syrian Woodpecker Dendrocopos syriacus in urban environments: an 
ambiguous effect of pollution. Bird Study 60:491-499. https:// doi.org/10.1080/00063657.2013.847899

Clayton DH, Wolfe ND (1993) The adaptive significance of self-medication. Trends Ecol Evol 8:60-63. https://doi.org/10.1016/01695347(93)90160-q

Cocker M, Tipling D (2013) Birds and People. Jonathan Cape, London

Collar NJ, Butchart SHM (2014) Conservation breeding and avian diversity: chances and challenges. Int Zoo Yearb 48:7-28. https ://doi.org/10.1111/izy.12039

Colston TJ, Jackson CR (2016) Microbiome evolution along divergent branches of the vertebrate tree of life: what is known and unknown. Mol Ecol 25:3776-3800. https://doi.org/10.1111/ mec. 13730

Cook MI, Beissinger SR, Toranzos GA, Rodriguez RA, Arendt WJ (2005) Microbial infection affects egg viability and incubation behavior in a tropical passerine. Behav Ecol 16:30-36. https:// doi.org/10.1093/beheco/arh131

Cooper CB (2017) Citizen science: how ordinary people are changing the face of discovery. Gerald Duckworth and Co Ltd, London

Coulson JC, Butterfield J, Thomas C (1983) The herring gull Larus argentatus as a likely transmitting agent of Salmonella montevideo to sheep and cattle. Epidemiol Infect 91:437-443. https:// doi.org/10.1017/s0022172400060472

Cox DTC, Plummer KE, Shanahan DF, Siriwardena GM, Fuller RA, Anderson K, Hancock S, Gaston KJ (2017) Doses of neighborhood nature: the benefits for mental health of living with nature. BioScience 67:147-155. https://doi.org/10.1093/biosci/biw173

Croci S, Butet A, Clergeau P (2008) Does urbanization filter birds on the basis of their biological traits? Condor 110:223-240. https:// doi.org/10.1525/cond.2008.8409

Davies ZG, Fuller RA, Loram A, Irvine KN, Sims V, Gaston KJ (2009) A national scale inventory of resource provision for biodiversity within domestic gardens. Biol Cons 142:761-771. https://doi.org/10.1016/j.biocon.2008.12.016

Davis AY, Major RE, Taylor CE (2014a) Distribution of tree-hollows and hollow preferences by parrots in an urban landscape. Emu 114:295-303. https://doi.org/10.1071/mu13065

Davis AY, Malas N, Minor ES (2014b) Substitutable habitats? The biophysical and anthropogenic drivers of an exotic bird's distribution. Biol Invasions 16:415-427. https://doi.org/10.1007/ s10530-013-0530-z

De Laet J, Summers-Smith J (2007) The status of the urban House Sparrow Passer domesticus in north-western Europe: a review. J Ornithol 148(Suppl 2):S275-S278. https://doi.org/10.1007/ s10336-007-0154-0

Deeming DC, Jarrett NS (2015) Applications of incubation science to aviculture and conservation. In: Deeming DC, Reynolds SJ (eds) Nests, eggs, \& incubation: new ideas about avian reproduction. Oxford University Press, Oxford, pp 196-207

Deeming DC, Reynolds SJ (eds) (2015a) Nests, eggs, \& incubation: new ideas about avian reproduction. Oxford University Press, Oxford

Deeming DC, Reynolds SJ (2015b) Perspectives on avian nests and eggs. In: Deeming DC, Reynolds SJ (eds) Nests, eggs, \& incubation: new ideas about avian reproduction. Oxford University Press, Oxford, pp 221-225

Deeming DC, Mainwaring MC, Hartley IR, Reynolds SJ (2012) Local temperature and not latitude determines the design of Blue Tit and Great Tit nests. Avian Biol Res 5:203-208. https ://doi.org/10.3184/175815512x13528874959581

Demeyrier V, Lambrechts MM, Perret P, Grégoire A (2016) Experimental demonstration of an ecological trap for a wild bird in a human-transformed environment. Anim Behav 118:181-190. https://doi.org/10.1016/j.anbehav.2016.06.007

Devictor V, Whittaker RJ, Beltrame C (2010) Beyond scarcity: citizen science programmes as useful tools for conservation biogeography. Divers Distrib 16:354-362. https://doi.org/10. 1111/j.1472-4642.2009.00615.x

Dias PC (1996) Sources and sinks in population biology. Trends Ecol Evol 11:326-330. https://doi.org/10.1016/0169-5347(96)10037 $-9$

Dickie IA, Bennett BM, Burrows LE, Nuñez MA, Peltzer DA, Porté A, Richardson DM, Rejmánek M, Rundel PW, van Wilgen BW (2014) Conflicting values: ecosystem services and invasive tree management. Biol Invasions 16:705-719. https://doi. org/10.1007/s10530-013-0609-6

Dickinson JL, Bonney R (2012) Citizen science: public participation in environmental research. Comstock Publishing Associates, Ithaca

Dolan RW, Moore ME, Stephens JD (2011) Documenting effects of urbanization on flora using herbarium records. J Ecol 99:10551062. https://doi.org/10.1111/j.1365-2745.2011.01820.x

Dominoni D, Quetting M, Partecke J (2013) Artificial light at night advances avian reproductive physiology. Proc Roy Soc B 280:20123017. https://doi.org/10.1098/rspb.2012.3017

Donovan TM, Thompson FR III (2001) Modeling the Ecological Trap Hypothesis: A habitat and demographic analysis for migrant songbirds. Ecol Appl 11:871-882. https://doi.org/10.1890/10510761(2001)011\%5b0871:mtetha\%5d2.0.co;2

Duckworth RA, Hallinger KK, Hall N, Potticary AL (2017) Switch to a novel breeding resource influences coexistence of two passerine birds. Front Ecol Evol 5:72. https://doi.org/10.3389/ fevo.2017.00072

Evans KL (2010) Individual species and urbanisation. In: Gaston KJ (ed) Urban Ecology. Cambridge University Press, Cambridge, pp 53-87

Evans KL, Gaston KJ, Sharp SP, McGowan A, Simeoni M, Hatchwell BJ (2009a) Effects of urbanisation on disease prevalence and age structure in blackbird Turdus merula populations. Oikos 118:774-782. https://doi.org/10.1111/j.1600-0706.2008.17226.x

Evans KL, Newson SE, Gaston KJ (2009b) Habitat influences on urban avian assemblages. Ibis 151:19-39. https://doi.org/10.1111/ j.1474-919x.2008.00898.x

Evans KL, Chamberlain DE, Hatchwell BJ, Gregory RD, Gaston KJ (2011) What makes an urban bird? Glob Change Biol 17:32-44. https://doi.org/10.1111/j.1365-2486.2010.02247.x

Faeth SH, Warren PS, Shochat E, Marussich WA (2005) Trophic dynamics in urban communities. BioScience 55:399-407. https://doi.org/10.1641/0006-3568(2005)055\%5b0399:tdiuc $\% 5 \mathrm{~d} 2.0 . \mathrm{co} ; 2$

Fagan WE, Cantrell RS, Cosner C (1999) How habitat edges change species interactions. Am Nat 153:165-182. https://doi. org/10.1086/303162

Fernández-Juricic E, Jokimäki J (2001) A habitat island approach to conserving birds in urban landscapes: case studies from southern and northern Europe. Biodivers Conserv 10:2023-2043. https:// doi.org/10.1023/a:1013133308987

Finn H, Stock W, Valentine L (2009) Pines and the ecology of Carnaby's black-cockatoos (Calyptorhynchus latirostris) in the Gnangara Sustainability Strategy study area. Report for the Forest Products Commission. Centre for Ecosystem Management Report no. 10-2009, Edith Cowan University, Perth, Australia

Forman RTT (2014) Urban ecology—science of cities. Cambridge University Press, Cambridge

Forsyth GG, Richardson DM, Brown PJ, van Wilgen BW (2004) A rapid assessment of the invasive status of Eucalyptus species in two South African provinces: working for water. S Afr J Sci 100:75-77

Fuller RA, Warren PH, Gaston KJ (2007) Daytime noise predicts nocturnal singing in urban robins. Biol Lett 3:368-370. https://doi. org/10.1098/rsbl.2007.0134 
Fuller RA, Irvine KN, Davies ZG, Armsworth PR, Gaston KJ (2012) Interactions between people and birds in urban landscapes. In: Lepczyk CA, Warren PS (eds) Urban bird ecology and conservation. Studies in avian biology (no. 45). University of California Press, Berkeley, pp 249-266

Furness RW, Greenwood JJD (1993) Birds as monitors of environmental change. Springer, Dordrecht

Galbraith JA, Beggs JR, Jones DN, Stanley MC (2015) Supplementary feeding restructures urban bird communities. Proc Natl Acad Sci USA 112:E2648-E2657. https://doi.org/10.1073/pnas.15014 89112

Gaston KJ, Warren PH, Thompson K, Smith RM (2005) Urban domestic gardens (IV): the extent of the resource and its associated features. Biol Cons 14:3327-3349. https://doi.org/10.1007/s1053 1-004-9513-9

Gehrt SD, Riley SPD, Cypher BL (eds) (2010) Urban carnivores. ecology, conflict, and conservation. Johns Hopkins University Press, Baltimore

Gil D, Brumm H (eds) (2013) Avian urban ecology: Behavioural and physiological adaptations. Oxford University Press, Oxford

Glądalski M, Bańbura M, Kaliński A, Markowski M, Skwarska J, Wawrzyniak J, Zieliński P, Cyżewska I, Bańbura J (2016) Effects of nest characteristics on reproductive performance in Blue Tits Cyanistes caeruleus and Great Tits Parus major. Avian Biol Res 9:37-43. https://doi.org/10.3184/175815516x14447556559088

Godefroid S, Ricotta C (2018) Alien plant species do have a clear preference for different land uses within urban environments. Urban Ecosyst 21:1189-1198. https://doi.org/10.1007/s1125 2-018-0792-4

Grarock K, Lindenmayer DB, Wood JT, Tidemann CR (2013) Does human-induced habitat modification influence the impact of introduced species? A case study on cavity-nesting by the introduced common myna (Acridotheres tristis) and the two Australian native parrots. Environ Manage 52:958-970. https://doi. org/10.1007/s00267-013-0088-7

Greenwood JJD (2007) Citizens, science and bird conservation. J Ornithol 148(Suppl 1):S77-S124. https://doi.org/10.1007/s1033 6-007-0239-9

Grimm NB, Faeth SH, Golubiewski NE, Redman CL, Wu J, Bai X, Briggs JM (2008) Global change and the ecology of cities. Science 319:756-760. https://doi.org/10.1126/science.1150195

Grond K, Sandercock BK, Jumpponen A, Zeglin LH (2018) The avian gut microbiota: community, physiology and function in wild birds. J Avian Biol 49:1-19. https://doi.org/10.1111/jav.01788

Hanmer HJ, Thomas RL, Beswick GJF, Collins BP, Fellowes MDE (2017) Use of anthropogenic material affects bird nest arthropod community structure: influence of urbanisation, and consequences for ectoparasites and fledging success. J Ornithol 158:1045-1059. https://doi.org/10.1007/s10336-017-1462-7

Hansell MH (2000) Bird nests and construction behaviour. Cambridge University Press, Cambridge

Harper MJ, McCarthy MA, van der Ree R (2005) The use of nest boxes in urban natural vegetation remnants by vertebrate fauna. Wildlife Res 32:509-516. https://doi.org/10.1071/wr04106

Hatch JJ (1996) Threats to public health from gulls (Laridae). Int J Environ Health Res 6:5-16. https://doi.org/10.1080/0960312960 9356867

Hedblom M, Söderström B (2012) Effects of urban matrix on reproductive performance of Great Tit (Parus major) in urban woodlands. Urban Ecosyst 15:167-180. https://doi.org/10.1007/s1125 2-011-0204-5

Henry P-Y, Wey G, Balança G (2011) Rubber band ingestion by a rubbish dump dweller, the White Stork (Ciconia ciconia). Waterbirds 34:504-508. https://doi.org/10.1675/063.034.0414

Hoffman B, Hoffman S (2009) Multifaceted rescue team save crowned eagle chick. Gabar 20:32-35
Holveck M-J, Grégoire A, Doutrelant C, Lambrechts MM (2019) Nest height is affected by lamppost lighting proximity in addition to nestbox size in urban great tits. J Avian Biol 2019:e01798. https ://doi.org/10.1111/jav.01798

Ibáñez-Álamo JD, Rubio E, Benedetti Y, Morelli F (2017a) Global loss of avian evolutionary uniqueness in urban areas. Glob Change Biol 23:2990-2998. https://doi.org/10.1111/gcb.13567

Ibáñez-Álamo JD, Rubio E, Bitrus Zira K (2017b) The degree of urbanization of a species affects how intensively it is studied: a global perspective. Front Ecol Evol 5:41. https://doi.org/10.3389/ fevo.2017.00041

Ibáñez-Álamo JD, Pineda-Pampliega J, Thomson RL, Aguirre JI, DíezFernández A, Faivre B, Figuerola J, Verhulst S (2018) Urban blackbirds have shorter telomeres. Biol Lett 14:6-9. https://doi. org/10.1098/rsbl.2018.0083

Igic B, Cassey P, Samas P, Grim T, Hauber ME (2009) Cigarette butts form a perceptually cryptic component of song thrush (Turdus philomelos) nests. Notornis 56:134-138

Isaksson C (2015) Urbanisation, oxidative stress and inflammation: a question of evolving, acclimatizing or coping with urban environmental stress. Funct Ecol 29:913-923. https://doi. org/10.1111/1365-2435.12477

Jagiello ZA, Dylewski Ł, Winiarska D, Zolnierowicz KM, Tobolka M (2018) Factors determining the occurrence of anthropogenic materials in nests of the white stork Ciconia ciconia. Environ Sci Pollut Res 25:14726-14733. https://doi.org/10.1007/s1135 6-018-1626-x

Jerzak L (2001) Synurbanization of the magpie in the Palearctic. In: Marzluff J, Bowman R, Donnelly R (eds) Avian ecology and conservation in an urbanizing world. Springer, New York, pp 403-425

Johnson MTJ, Munshi-South J (2017) Evolution of life in urban environments. Science 358:eaam8327. https://doi.org/10.1126/ science.aam 8327

Jokimäki J (1999) Occurrence of breeding bird species in urban parks: effects of park structure and broad-scale variables. Urban Ecosyst 3:21-34. https://doi.org/10.1023/a:1009505418 327

Jokimäki J, Suhonen J, Kaisanlahti-Jokimäki M-J (2018) Urban core areas are important for species conservation: a European-level analysis of breeding bird species. Landsc Urban Plan 178:7381. https://doi.org/10.1016/j.landurbplan.2018.05.020

Jones D (2008) Wildlife management in the extreme: managing magpies and mothers in a suburban environment. In: Lunney D, Munn A, Meikle W (eds) Too close for comfort: contentious issues in human-wildlife encounters. Royal Society of New South Wales, Sydney, pp 9-14

Jones DN (2018) The birds at my table: why we feed wild birds and why it matters. Comstock Publishing Associates, Ithaca

Jones DN, Everding SE (1991) Australian Brush-turkeys in a suburban environment: implications for conflict and conservation. Wildlife Res 18:285-297. https://doi.org/10.1071/wr9910285

Jones DN, Reynolds SJ (2008) Feeding birds in our towns and cities: a global research opportunity? J Avian Biol 39:265-271. https ://doi.org/10.1111/j.0908-8857.2008.04271.x

Kark S, Iwaniuk A, Schalimtzek A, Banker E (2007) Living in the city: can anyone become an 'urban exploiter'? J Biogeogr 34:638-651. https://doi.org/10.1111/j.1365-2699.2006.01638 .x

Kempenaers B, Borgström P, Loës P, Schlicht E, Valcu M (2010) Artificial night lighting affects dawn song, extra-pair siring success, and lay date in songbirds. Curr Biol 20:1735-1739. https://doi. org/10.1016/j.cub.2010.08.028

Kettel EF, Gentle LK, Quinn JL, Yarnell RW (2018) The breeding performance of raptors in urban landscapes: a review and 
meta-analysis. J Ornithol 159:1-18. https://doi.org/10.1007/ s10336-017-1497-9

Khera N, Mehta V, Sabata BC (2009) Interrelationships of birds and habitat features in urban greenspaces in Delhi, India. Urban For Urban Gree 8:187-196. https://doi.org/10.1016/j. ufug.2009.05.001

Kokko H, Sutherland WJ (2001) Ecological traps in changing environments: ecological and evolutionary consequences of a behaviourally mediated Allee effect. Evol Ecol Res 3:603-610

Kristan WB III (2003) The role of habitat selection behavior in population dynamics: source-sink systems and ecological traps. Oikos 103:457-468. https://doi.org/10.1034/j.1600-0706.2003.12192.x

La Sala LF, Petracci PF, Randazzo V, Fernández-Miyakawa ME (2013) Enteric bacteria in Olrog's Gull (Larus atlanticus) and Kelp Gull (Larus dominicanus) from the Bahía Blanca Estuary, Argentina. Hornero 28:59-64

Lambrechts MM, Charmantier A, Demeyrier V, Lucas A, Perret S, Abouladzé M, Bonnet M, Canonne C, Faucon V, Grosset S, le Prado G, Lidon F, Noell T, Pagano P, Perret V, Pouplard S, Spitaliéry R, Bernard C, Perret P, Blondel J, Grégoire A (2017) Nest design in a changing world: great tit Parus major nests from a Mediterranean city environment as a case study. Urban Ecosyst 20:1181-1190. https://doi.org/10.1007/s11252-017-0670-5

Lee K, Jang YC, Hong S, Lee J, Kwon K (2015) Plastic marine debris used as nesting materials of the endangered species black-faced spoonbill Platalea minor decreases by conservation activities. J Korean Soc Mar Environ Energy 18:45-49. https://doi. org/10.7846/jkosmee.2015.18.1.45

Lepczyk CA, Warren PS (eds) (2012) Urban bird ecology and conservation. Studies in avian biology (no. 45). University of California Press, Berkeley

Lepczyk CA, Warren PS, Machabée L, Kinzig AP, Mertig AG (2012) Who feeds the birds: a comparison across regions. In: Lepczyk CA, Warren PS (eds) Urban bird ecology and conservation. Studies in avian biology (no. 45). University of California Press, Berkeley, pp 267-282

Lesiński G (2000) Location of bird nests in vertical metal pipes in suburban built-up area of Warsaw. Acta Ornithol 35:211-214. https://doi.org/10.3161/068.035.0203

Leston LF, Rodewald AD (2006) Are urban forests ecological traps for understory birds? An examination using Northern Cardinals. Biol Cons 131:566-574. https://doi.org/10.1016/j.biocon.2006.03.003

Lloyd P, Martin TE, Redmond RL, Langner U, Hart MM (2005) Linking demographic effects of habitat fragmentation across landscapes to continental source-sink dynamics. Ecol Appl 15:15041514. https://doi.org/10.1890/04-1243

López-Flores V, MacGregor-Fors I, Schondube JE (2009) Artificial nest predation along a Neotropical urban gradient. Landsc Urban Plan 92:90-95. https://doi.org/10.1016/j.landurbpla n.2009.03.001

Loyn R, Lane B, Chandler C, Carr G (1986) Ecology of Orange-Bellied Parrots Neophema chrysogaster at their main remnant wintering site. Emu 86:195-206. https://doi.org/10.1071/mu9860195

Luck G, Smallbone L (2010) Species diversity and urbanisation: Patterns, drivers and implications. In: Gaston KJ (ed) Urban Ecology. Cambridge University Press, Cambridge, pp 88-119

Luniak M (2004) Synurbization-adaptation of animal wildlife to urban development. In: Shaw WW, Harris LK, VanDruff L (eds) Proceedings of the 4th International Symposium on Urban Wildlife Conservation. May 1-5, 1999, Tucson, pp 50-55

Mainwaring MC (2015) The use of man-made structures as nesting sites by birds: a review of the costs and benefits. J Nat Conserv 25:17-22. https://doi.org/10.1016/j.jnc.2015.02.007

Mainwaring MC, Hartley IR, Bearhop S, Brulez K, du Feu C, Murphy G, Plummer KE, Webber SL, Reynolds SJ, Deeming DC (2012) Latitudinal variation in blue tit and great tit nest characteristics indicates environmental adaptation. J Biogeogr 39:1669-1677. https://doi.org/10.1111/j.1365-2699.2012.02724.x

Mainwaring MC, Deeming DC, Jones CI, Hartley IR (2014a) Adaptive latitudinal variation in Common Blackbird Turdus merula nest characteristics. Ecol Evol 4:841-851. https://doi.org/10.1002/ ece 3.952

Mainwaring MC, Hartley IR, Lambrechts MM, Deeming DC (2014b) The design and function of birds' nests. Ecol Evol 4:3909-3928. https://doi.org/10.1002/ece3.1054

Mainwaring MC, Reynolds SJ, Weidinger K (2015) The influence of predation on the location and design of nests. In: Deeming DC, Reynolds SJ (eds) Nests, eggs, \& incubation: new ideas about avian reproduction. Oxford University Press, Oxford, pp 50-64

Mainwaring MC, Wolfenden A, Read JE, Robson JMA, Tomlinson CJ, Hartley IR (2016) Feathering the nest: the effects of feather supplementation to Blue Tit nests. Avian Biol Res 9:89-95. https ://doi.org/10.3184/175815516x14551240159329

Malan G, Robinson ER (2001) Nest-site selection by Black Sparrowhawks Accipiter melanoleucus: implications for managing exotic pulpwood and sawlog forests in South Africa. Environ Manage 28:195-205. https://doi.org/10.1007/s002670010

Malan G, Shultz S (2002) Nest-site selection of the crowned hawkeagle in the forests of KwaZulu-Natal, South Africa, and Tai, Ivory Coast. J Raptor Res 36:300-308

Martin RO, Sebele L, Koeslag A, Curtis O, Abadi F, Amar A (2014) Phenological shifts assist colonisation of a novel environment in a range-expanding raptor. Oikos 123:1457-1468. https://doi. org/10.1111/oik.01058

Marzluff JM (2014) Welcome to Subirdia: Sharing our Neighborhoods with Wrens, Robins, Woodpeckers, and other wildlife. Yale University Press, New Haven

Marzluff JM (2017) A decadal review of urban ornithology and a prospectus for the future. Ibis 159:1-13. https://doi.org/10.1111/ ibi. 12430

Marzluff JM, Ewing K (2001) Restoration of fragmented landscapes for the conservation of birds: a general framework and specific recommendations for urbanizing landscapes. Restor Ecol 9:280-292. https://doi.org/10.1046/j.1526-100x.2001.00900 $3280 . x$

Marzluff JM, Bowman R, Donnelly R (eds) (2001) Avian ecology and conservation in an urbanizing world. Kluwer Academic Publishers, Boston

McFall-Ngai M, Hadfield MG, Bosch TCG, Carey HV, DomazetLošo T, Douglas AE, Dubilier N, Eberl G, Fukami T, Gilbert SF, Hentschel U, King N, Kjelleberg S, Knoll AH, Kremer N, Mazmanian SK, Metcalf JL, Nealson K, Pierce NE, Rawls JF, Reid A, Ruby EG, Rumpho M, Sanders JG, Tautz D, Wernegreen JJ (2013) Animals in a bacterial world, a new imperative for the life sciences. Proc Natl Acad Sci USA 110:3229-3236. https:// doi.org/10.1073/pnas.1218525110

McKinney ML (2006) Urbanization as a major cause of biotic homogenization. Biol Cons 127:247-260. https://doi.org/10.1016/j. biocon.2005.09.005

McKinney ML (2008) Effects of urbanization on species richness: a review of plants and animals. Urban Ecosyst 11:161-176. https ://doi.org/10.1007/s11252-007-0045-4

McPherson SC, Brown M, Downs CT (2016a) Crowned eagle nest sites in an urban landscape: requirements of a large eagle in the Durban Metropolitan Open Space System. Landsc Urban Plan 146:43-50. https://doi.org/10.1016/j.landurbplan.2015.10.004

McPherson SC, Brown M, Downs CT (2016b) Diet of the crowned eagle (Stephanoaetus coronatus) in an urban landscape: potential for human-wildlife conflict? Urban Ecosyst 19:383-396. https:// doi.org/10.1007/s11252-015-0500-6 
Meyer LM, Schmidt KA, Robertson BA (2015) Evaluating exotic plants as evolutionary traps for nesting veeries. Condor 117:320-327. https://doi.org/10.1650/condor-14-101.1

Miller JR, Hobbs RJ (2002) Conservation where people live and work. Conserv Biol 16:330-337. https://doi.org/10.104 6/j.1523-1739.2002.00420.x

Møller AP (2010) Interspecific variation in fear responses predicts urbanization in birds. Behav Ecol 21:365-371. https://doi. org/10.1093/beheco/arp199

Møller AP, Díaz M (2018) Avian preference for close proximity to human habitation and its ecological consequences. Curr Zool 64:623-630. https://doi.org/10.1093/cz/zox073

Müller N, Ignatieva M, Nilon CH, Werner P, Zipperer WC (2013) Patterns and trends in urban biodiversity and landscape design. In: Elmqvist T, Fragkias M, Goodness J, Güneralp B, Marcotullio PJ, McDonald RI, Parnell S, Schewenius M, Sendstad M, Seto KC, Wilkinson C (eds) Urbanization, biodiversity, and ecosystem services: challenges and opportunities. Springer, New York, pp 123-174. https://doi.org/10.1007/978-94-007-7088-1_10

Munro CA (1984) Roof nesting oystercatchers. Bird Study 31:148. https://doi.org/10.1080/00063658409476833

Murcia C (1995) Edge effects in fragmented forests-Implications for conservation. Trends Ecol Evol 10:58-62. https://doi. org/10.1016/s0169-5347(00)88977-6

Murgui E, Hedblom M (2017) Ecology and conservation of birds in urban environments. Springer International Publishing AG, Cham

Norris K, Pain DJ (eds) (2002) Conserving bird biodiversity: general principles and their application. Cambridge University Press, Cambridge

Oke TR (1982) The energetic basis of the urban heat island. Q J Roy Meteor Soc 108:1-24. https://doi.org/10.1002/qj.49710845502

Oliveira Hagen E, Hagen O, Ibáñez-Álamo JD, Petchey OL, Evans KL (2017) Impacts of urban areas and their characteristics on avian functional diversity. Front Ecol Evol 5:84. https://doi. org/10.3389/fevo.2017.00084

Ortega YK, McKelvey KS, Six DL (2006) Invasion of an exotic forb impacts reproductive success and site fidelity of a migratory songbird. Oecologia 149:340-351. https://doi.org/10.1007/s0044 2-006-0438-8

Parker GH, Blomme CG (2007) Fish-line entanglement of nesting mourning dove, Zenaida macroura. Can Field-Nat 121:436-437. https://doi.org/10.22621/cfn.v121i4.522

Partecke J, Van't Hof T, Gwinner E (2004) Difference in the timing of reproduction between urban and forest European Blackbirds (Turdus merula): result of phenotypic flexibility or genetic differences? Proc Roy Soc B 271:1995-2001. https://doi.org/10.1098/ rspb.2004.2821

Peralta-Sánchez JM, Møller AP, Martin-Platero AM, Soler JJ (2010) Number and colour composition of nest lining feathers predict eggshell bacterial community in barn swallow nests: an experimental study. Funct Ecol 24:426-433. https://doi.org/10.111 1/j.1365-2435.2009.01669.x

Peralta-Sánchez JM, Martín-Platero AM, Wegener-Parfrey L, Martínez-Bueno M, Rodríguez-Ruano S, Navas-Molina J, VázquezBaeza Y, Martín-Gálvez D, Martín-Vivaldi M, Ibáñez-Álamo JD, Knight R, Soler JJ (2018) Bacterial density rather than diversity correlates with hatching success across different avian species. FEMS Microbiol Ecol 94:1-13. https://doi.org/10.1093/femsec/ fiy022

Poessel SA, Breck SW, Teel TL, Shwiff S, Crooks KR, Angeloni L (2012) Patterns of human-coyote conflicts in the Denver metropolitan area. J Wildl Manage 77:297-305. https://doi. org/10.1002/jwmg.454
Postupalsky S, Stackpole SM (1974) Artificial nesting platforms for Ospreys in Michigan. In: Proceedings of a conference on raptor conservation techniques, Fort Collins, pp. 105-117

Provencher JF, Bond A, Mallory ML, Avery-Gomm S, Borrelle S, Bravo-Rebolledo E, Hammer S, Kühn S, Lavers J, Mallory M, Trevail A, van Franeker J (2017) Quantifying ingested debris in marine megafauna: a review and recommendations for standardization. Anal Methods-UK 9:1454-1469. https://doi.org/10.1039/ c6ay02419j

Radhamany D, Anoop Das KS, Azeez PA, Wen L, Sreekala LK (2016) Usage of nest materials by house sparrow (Passer domesticus) along an urban to rural gradient in Coimbatore, India. Trop Life Sci Res 27:127-134. https://doi.org/10.21315/tlsr2016.27.2.10

Rao S, Koli VK (2017) Edge effect of busy high traffic roads on the nest site selection of birds inside the city area: guild response. Transp Res D Transp Environ 51:94-101. https://doi.org/10.1016/j. trd.2016.12.013

Raven S, Coulson JC (1997) The distribution and abundance of Larus gulls nesting on buildings in Britain and Ireland. Bird Study 44:13-34. https://doi.org/10.1080/00063659709461035

Reale JA, Blair RB (2005) Nesting success and life history attributes of bird communities along an urbanization gradient. Urban Habitats $3: 1-24$

Redpath SM, Young J, Evely A, Adams WM, Sutherland WJ, Whitehouse A, Amar A, Lambert RA, Linnell JDC, Watt A, Gutiérrez RJ (2013) Understanding and managing conservation conflicts. Trends Ecol Evol 28:100-109. https://doi.org/10.1016/j. tree.2012.08.021

Reid JM, Cresswell W, Holt S, Mellanby RJ, Whitfield DP, Ruxton GD (2002) Nest scrape design and clutch heat loss in Pectoral Sandpipers (Calidris melanotos). Funct Ecol 16:305-312. https ://doi.org/10.1046/j.1365-2435.2002.00632.x

Remacha C, Delgado JA (2009) Spatial nest-box selection of cavitynesting bird species in response to proximity to recreational infrastructures. Landsc Urban Plan 93:46-53. https://doi. org/10.1016/j.landurbplan.2009.06.004

Reynolds SJ, Deeming DC (2015) Incubating new ideas about avian reproduction. In: Deeming DC, Reynolds SJ (eds) Nests, eggs, $\&$ incubation: new ideas about avian reproduction. Oxford University Press, Oxford, pp 1-7

Reynolds SJ, Davies CS, Elwell E, Tasker PJ, Williams A, Sadler JP, Hunt D (2016) Does the urban gradient influence the composition and ectoparasite load of nests of an urban bird species? Avian Biol Res 9:224-234. https://doi.org/10.3184/17581 $5516 \times 14725499175665$

Reynolds SJ, Galbraith JA, Smith JA, Jones DN (2017) Garden bird feeding: insights and prospects from a north-south comparison of this global urban phenomenon. Front Ecol Evol 5:24. https ://doi.org/10.3389/fevo.2017.00024

Ribic CA, Thompson FR III, Pietz PJ (eds) (2012) Video Surveillance of Nesting Birds. Studies in avian biology (no. 43). University of California Press, Berkeley

Ripple WJ, Wolf C, Newsome TM, Galetti M, Alamgir M, Crist E, Mahmoud MI, Laurance WF (2017) World scientists' warning to humanity: a second notice. BioScience 67:1026-1028. https ://doi.org/10.1093/biosci/bix 125

Robb GN, McDonald RA, Chamberlain DE, Bearhop S (2008) Food for thought: supplementary feeding as a driver of ecological change in avian populations. Front Ecol Environ 6:476-484. https://doi.org/10.1890/060152

Robertson BA, Hutto RL (2006) A framework for understanding ecological traps and an evaluation of existing evidence. Ecology 87:1075-1085. https://doi.org/10.1890/00129658(2006)87\%5b1075:affuet\%5d2.0.co;2 
Rodewald AD, Shustack DP, Hitchcock LE (2010) Exotic shrubs as ephemeral ecological traps for nesting birds. Biol Invasions 12:33-39. https://doi.org/10.1007/s10530-009-9426-3

Rodewald AD, Kearns LJ, Shustack DP (2013) Consequences of urbanizing landscapes to reproductive performance of birds in remnant forests. Biol Cons 160:32-39. https://doi. org/10.1016/j.biocon.2012.12.034

Ruiz-Castellano C, Tomás G, Ruiz-Rodríguez M, Martín-Gálvez D, Soler JJ (2016) Nest material shapes eggs bacterial environment. PLoS ONE 11:e0148894. https://doi.org/10.1371/journ al.pone. 0148894

Šálek M, Riegert J, Grill S (2015) House Sparrows Passer domesticus and Tree Sparrows Passer montanus: fine-scale distribution, population densities, and habitat selection in a Central European city. Acta Ornithol 50:221-232. https://doi. org/10.3161/00016454ao2015.50.2.010

Sanz JJ, García-Navas V (2011) Nest ornamentation in blue tits: is feather carrying ability a male status signal? Behav Ecol 22:240-247. https://doi.org/10.1093/beheco/arq199

Schaub T, Meffert PJ, Kerth G (2015) Nest-boxes for Common Swifts Apus apus as compensatory measures in the context of building renovation: efficacy and predictors of occupancy. Bird Conserv Int 26:164-176. https://doi.org/10.1017/s0959 270914000525

Schlaepfer MA, Runge MC, Sherman PW (2002) Ecological and evolutionary traps. Trends Ecol Evol 7:474-480. https://doi. org/10.1016/s0169-5347(02)02580-6

Schlaepfer MA, Sax DF, Olden JD (2011) The potential conservation value of non-native species. Conserv Biol 25:428-437. https:// doi.org/10.1111/j.1523-1739.2010.01646.x

Schlossberg S, King DI (2010) Effects of invasive woody plants on avian nest site selection and nesting success in shrublands. Anim Cons 13:286-293. https://doi.org/10.111 $1 / \mathrm{j} .1469-1795.2009 .00338 . x$

Sergio F, Blas J, Blanco G, Tanferna A, López L, Lemus JA, Hiraldo F (2011) Raptor nest decorations are a reliable threat against conspecifics. Science 331:327-330. https://doi.org/10.1126/scien ce. 1199422

Seto KC, Güneralp B, Hutyrac LR (2012) Global forecasts of urban expansion to 2030 and direct impacts on biodiversity and carbon pools. Proc Natl Acad Sci USA 109:16083-16088. https://doi. org/10.1073/pnas.1211658109

Shafroth PB, Beauchamp VB, Briggs MK, Lair K, Scott ML, Sher AA (2008) Planning riparian restoration in the context of Tamarix control in western North America. Restor Ecol 16:97-112. https ://doi.org/10.1111/j.1526-100x.2008.00360.x

Shanahan DF, Strohbach MW, Warren PS, Fuller RA (2014) The challenges of urban living. In: Gil D, Brumm H (eds) Avian urban ecology: behavioural and physiological adaptations. Oxford University Press, Oxford, pp 3-20

Shipley AA, Murphy AT, Elzinga AH (2013) Residential edges as ecological traps: postfledging survival of a ground-nesting passerine in a forested urban park. Auk 130:501-511. https://doi. org/10.1525/auk.2013.12139

Sierro J, Schloesing E, Pavón I, Gil D (2017) European Blackbirds exposed to aircraft noise advance their chorus, modify their song and spend more time singing. Front Ecol Evol 5:68. https://doi. org/10.3389/fevo.2017.00068

Smith MD, Courtney JC, Lisa A (2005) Burrowing owl nesting productivity: a comparison between artificial and natural burrows on and off golf courses. Wildl Soc Bull 33:454-462. https://doi. org/10.2193/0091-7648(2005)33\%5b454:bonpac\%5d2.0.co;2

Smith JA, Cooper CB, Reynolds SJ (2015) Advances in techniques to study incubation. In: Deeming DC, Reynolds SJ (eds) Nests, eggs, \& incubation: new ideas about avian reproduction. Oxford University Press, Oxford, pp 179-195
Sohi GK, Kler TK (2017) Adaptations in avian nesting behavior in relation to indigenous trees and housing structures in Punjab. $\mathrm{J}$ Entomol Zool Stud 5:1045-1051

Sol D, González-Lagos C, Moreira D, Maspons J, Lapiedra O (2014) Urbanisation tolerance and the loss of avian diversity. Ecol Lett 17:942-950. https://doi.org/10.1111/ele.12297

Soldatini C, Albores-Barajas YV, Mainardi D, Monaghan P (2008) Roof nesting by gulls for better or worse? Ital J Zool 75:295-303. https://doi.org/10.1080/11250000701884805

Stanley TR (2002) How many kilojoules does a Black-billed Magpie nest cost? J Field Ornithol 73:292-297. https://doi. org/10.1648/0273-8570-73.3.292

Stinson LT, Pejchar L (2018) The effects of introduced plants on songbird reproductive success. Biol Invasions 20:1403-1416. https:// doi.org/10.1007/s10530-017-1633-8

Strubbe D, Matthysen E (2007) Invasive ring-necked parakeets Psittacula krameri in Belgium: habitat selection and impact on native birds. Ecography 30:578-588. https://doi.org/10.111 1/j.0906-7590.2007.05096.x

Strubbe D, Matthysen E (2009) Establishment success of invasive ringnecked and monk parakeets in Europe. J Biogeogr 36:2264-2278. https://doi.org/10.1111/j.1365-2699.2009.02177.x

Suárez-Rodríguez M, Macías Garcia C (2014) There is no such a thing as a free cigarette; lining nests with discarded butts brings shortterm benefits, but causes toxic damage. J Evol Biol 27:27192726. https://doi.org/10.1111/jeb.12531

Suárez-Rodríguez M, Macías Garcia C (2017) An experimental demonstration that house finches add cigarette butts in response to ectoparasites. J Avian Biol 48:1316-1321. https://doi. org/10.1111/jav.01324

Suárez-Rodríguez M, López-Rull I, Garcia CMÍ (2013) Incorporation of cigarette butts into nests reduces nest ectoparasite load in urban birds: new ingredients for an old recipe? Biol Lett 9:12-15. https://doi.org/10.1098/rsbl.2012.0931

Suárez-Rodríguez M, Montero-Montoya RD, Macías Garcia C (2017) Anthropogenic nest materials may increase breeding costs for urban birds. Front Ecol Evol 5:4. https://doi. org/10.3389/fevo.2017.00004

Sumasgutner P, Nemeth E, Tebb G, Krenn HW, Gamauf A (2014a) Hard times in the city - Attractive nest sites but insufficient food supply lead to low reproductive rates in a bird of prey. Front Zool 11:48. https://doi.org/10.1186/1742-9994-11-48

Sumasgutner P, Schulze CH, Krenn HW, Gamauf A (2014b) Conservation related conflicts in the nest-site selection of the Eurasian Kestrel (Falco tinnunculus) and the distribution of its avian prey. Landsc Urban Plan 127:94-103. https://doi.org/10.1016/j. landurbplan.2014.03.009

Tarboton WR (2001) A guide to the nests and eggs of Southern African birds. Struik, Cape Town

Tidemann S, Gosler A (2010) Ethno-ornithology: birds, indigenous peoples, culture and society. Earthscan, London

Tigner JR, Call MW, Kochert MN (1996) Effectiveness of artificial nesting structures for ferruginous hawks in Wyoming. In: Bird DM, Varland DE, Negro JJ (eds) Raptors in human landscapes: adaptations to built and cultivated environments. Academic Press, San Diego, pp 137-144

Toft R (2014) National birds of the world. Bloomsbury, London

Tomiałojć L (2016) Human initiation of synurbic populations of waterfowl, raptors, pigeons and cage birds. In: Murgui E, Hedblom M (eds) Ecology and conservation of birds in urban environments. Springer, Heidelberg, pp 271-286

Townsend AK, Barker CM (2014) Plastic and the nest entanglement of urban and agricultural crows. PLoS ONE 9:1-5. https://doi. org/10.1371/journal.pone.0088006

Tremblay I, Thomas DW, Lambrechts MM, Blondel J, Perret P (2003) Variation in Blue Tit breeding performance across 
gradients in habitat richness. Ecology 84:3033-3043. https:// doi.org/10.1890/02-0663

Treves A, Wallace RB, Naughton-Treves L, Morales A (2006) Comanaging human-wildlife conflicts: a review. Human Dim Wildl 11:383-396. https://doi.org/10.1080/108712006009842 65

Tryjanowski P, Kosicki JZ, Kuźniak S, Sparks TH (2009) Long-term changes and breeding success in relation to nesting structures used by the white stork, Ciconia ciconia. Ann Zool Fennici 46:34-38. https://doi.org/10.5735/086.046.0104

Turpie JK, Marais C, Blignaut JN (2008) The working for water programme: evolution of a payments for ecosystem services mechanism that addresses both poverty and ecosystem service delivery in South Africa. Ecol Econ 65:788-798. https://doi. org/10.1016/j.ecolecon.2007.12.024

United Nations (2014) World urbanization prospects: the 2014 revision, highlights (ST/ESA/SER.A/352). The United Nations, New York

Vermeer K, Power D, Smith GEJ (1988) Habitat selection and nesting biology of roof-nesting Glaucous-winged Gulls. Colon Waterbird 11:189-201. https://doi.org/10.2307/1521000

Vincze E, Seress G, Lagisz M, Nakagawa S, Dingemanse N, Sprau P (2017) Does urbanization affect predation of bird nests? A meta-analysis. Front Ecol Evol 5:29. https://doi.org/10.3389/ fevo.2017.00029

Wang Y, Chen S, Jiang P, Ding P (2008) Black-billed Magpies (Pica pica) adjust nest characteristics to adapt to urbanization in Hangzhou, China. Can J Zool 86:676-684. https://doi.org/10.1139/ z08-045
Wang Y, Chen S, Blair RB, Jiang P, Ding P (2009) Nest composition adjustments by Chinese Bulbuls Pycnonotus sinensis in an urbanized landscape of Hangzhou (E China). Acta Ornithol 44:185-192. https://doi.org/10.3161/000164509x482768

Wang Y, Huang Q, Lan S, Zhang Q, Chen S (2015) Common blackbirds Turdus merula use anthropogenic structures as nesting sites in an urbanized landscape. Curr Zool 61:435-443. https://doi. org/10.1093/czoolo/61.3.435

Welz A, Jenkins A (2005) How green is the valley? Monitoring fish eagles along the Breede River. Africa-Birds \& Birding 10:30-37

Wesołowski T (2011) Reports from nestbox studies: a review of inadequacies. Acta Ornithol 46:13-17. https://doi.org/10.3161/00016 $4511 \times 589866$

Wesołowski T, Stanska M (2001) High ectoparasite loads in holenesting birds - A nestbox bias? J Avian Biol 32:281-285. https ://doi.org/10.1111/j.0908-8857.2001.320313.x

Wimberger PH (1984) The use of green plant material in bird nests to avoid ectoparasites. Auk 101:615-618. https://doi. org/10.1016/0376-7388(93)85176-w

Publisher's Note Springer Nature remains neutral with regard to jurisdictional claims in published maps and institutional affiliations. 